Prepared in cooperation with the Indiana Office of Community and Rural Affairs

\title{
Regional Bankfull-Channel Dimensions of Non-Urban Wadeable Streams in Indiana
}

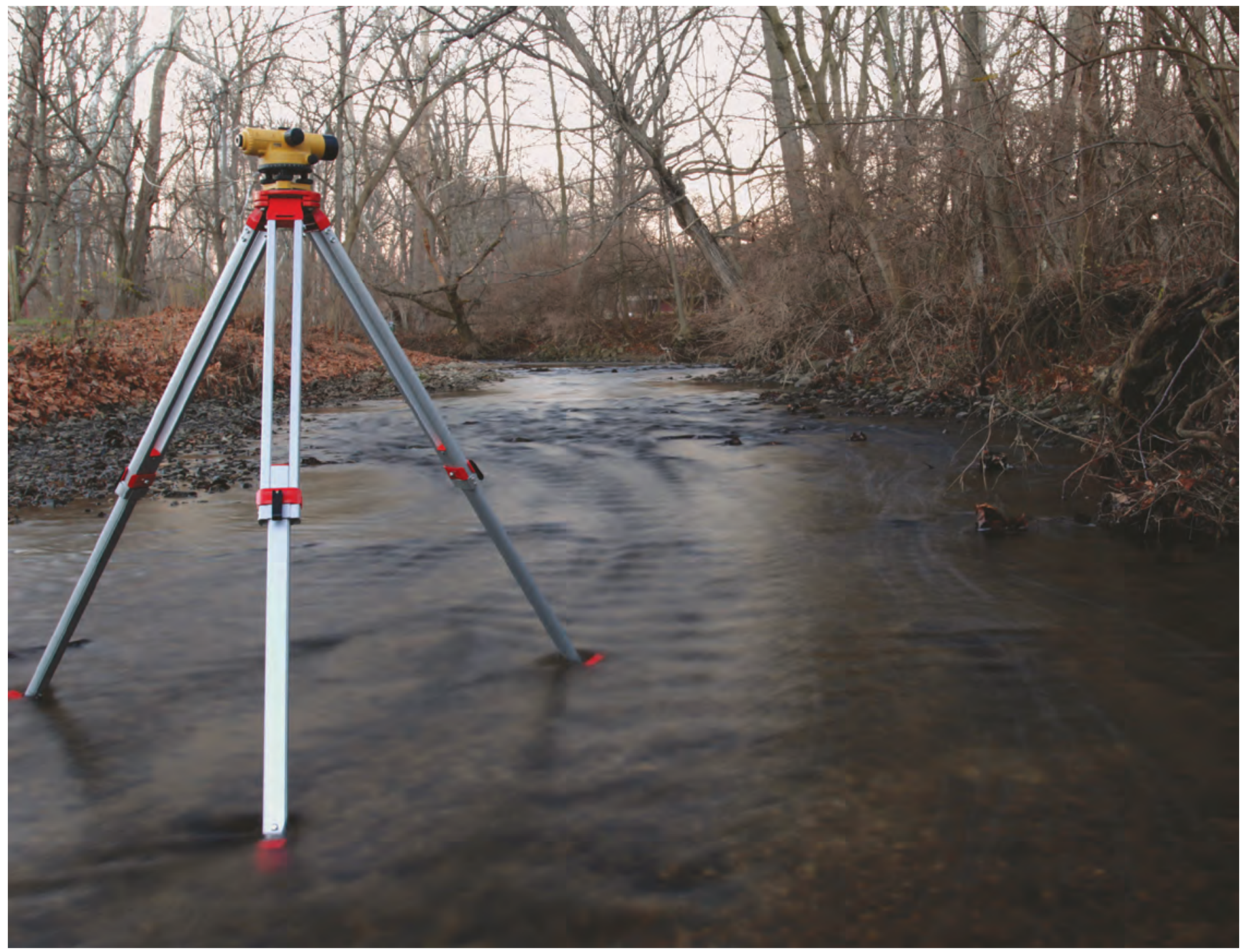

Scientific Investigations Report 2013-5078

U.S. Department of the Interior U.S. Geological Survey 
Cover Photograph: Pleasant Run Creek at Greenwood, Indiana. (Photograph by Bret A. Robinson, U.S. Geological Survey, taken January 24, 2013.) 


\section{Regional Bankfull-Channel Dimensions of Non-Urban Wadeable Streams in Indiana}

By Bret A. Robinson

Prepared in cooperation with the Indiana Office of Community and Rural Affairs

Scientific Investigations Report 2013-5078 


\title{
U.S. Department of the Interior SALLY JEWELL, Secretary
}

\section{U.S. Geological Survey \\ Suzette M. Kimball, Acting Director}

\author{
U.S. Geological Survey, Reston, Virginia: 2013
}

For more information on the USGS - the Federal source for science about the Earth, its natural and living resources, natural hazards, and the environment, visit http://www.usgs.gov or call 1-888-ASK-USGS.

For an overview of USGS information products, including maps, imagery, and publications, visit http://www.usgs.gov/pubprod

To order this and other USGS information products, visit http://store.usgs.gov

Any use of trade, firm, or product names is for descriptive purposes only and does not imply endorsement by the U.S. Government.

Although this information product, for the most part, is in the public domain, it also may contain copyrighted materials as noted in the text. Permission to reproduce copyrighted items must be secured from the copyright owner.

Suggested citation:

Robinson, B.A., 2013, Regional bankfull-channel dimensions of non-urban wadeable streams in Indiana: U.S. Geological Survey, Scientific Investigations Report 2013-5078, 33 p. 


\section{Contents}

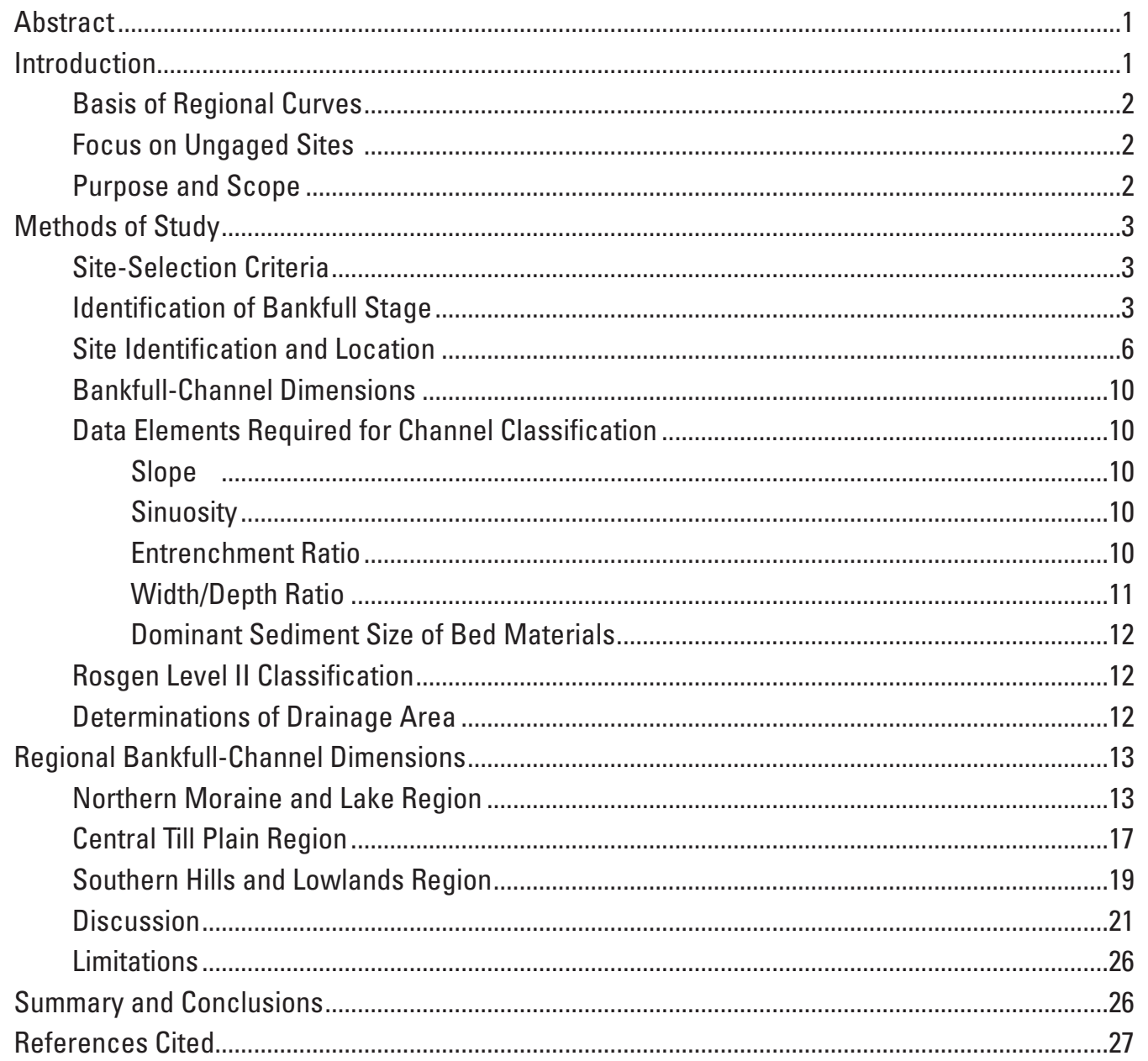

Appendix 1. Channel-classification data and determinations for the channel-dimension study sites on non-urban wadeable streams in Indiana .......................................................

\section{Figures}

1. Map showing physiographic regions and sections of Indiana ........................................

2. Photographs showing the three most frequently observed field indicators of

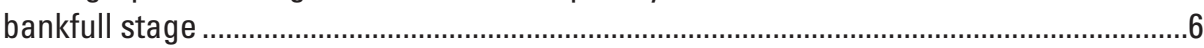

3. Map showing location of the 82 sites where bankfull-channel-dimension data were collected in Indiana ..................................................................................................7

4. Photographs showing field activities to establish the boundaries of measurement cross-sections where bankfull-channel-dimension data were collected ........................11

5. Diagram illustrating steps taken to determine entrenchment ratios ..............................11 
6. Photograph showing gravelometer used to determine the dominant particle size of bed materials for sites with abundant gravel- and(or) cobble-sized particles.

7. Photograph showing three selected channel reaches generally seen to be representative of Indiana's contrasting physiographic regions: a reach of Little Elkhart Creek in Wolcottville $(N)$ in the Northern Moraine and Lake region, a reach of White Lick Creek at Avon $(C)$ in the Central Till Plain region, and an unnamed tributary to Bear Creek in Yellowwood State Forest $(S)$ in the Southern Hills and Lowlands region.

8. Plot showing regional channel-dimension curves for estimating bankfull-channel width, mean depth, and cross-sectional area of non-urban wadeable streams in the Northern Moraine and Lake physiographic region of Indiana...

9. Plot showing regional channel-dimension curves for estimating bankfull-channel width, mean depth, and cross-sectional area of non-urban wadeable streams in the Central Till Plain physiographic region of Indiana

10. Plot showing regional channel-dimension curves for estimating bankfull-channel width, mean depth, and cross-sectional area of non-urban wadeable streams in the Southern Hills and Lowlands physiographic region of Indiana...

11. Plot showing comparison of the regional channel-dimension curves for estimating bankfull-channel width of non-urban wadeable streams in Indiana

12. Plot showing comparison of the regional channel-dimension curves for estimating mean bankfull-channel depth of non-urban wadeable streams in Indiana

13. Plot showing comparison of the regional channel-dimension curves for estimating bankfull-channel cross-sectional area of non-urban wadeable streams in Indiana......25

\section{Tables}

1. Location information for the 82 sites where data were collected to document bankfull-channel dimensions of non-urban wadeable streams in Indiana

2. Drainage areas and bankfull-channel dimensions of study sites in the Northern Moraine and Lake region of Indiana.....

3. Drainage areas and bankfull-channel dimensions of study sites in the Central Till Plain region of Indiana.

4. Drainage areas and bankfull-channel dimensions of study sites in the Southern Hills and Lowlands region of Indiana...

5. Regression equations for estimating bankfull-channel dimensions of non-urban wadeable streams in Indiana.

6. Comparison of bankfull-channel-dimension estimates from Indiana and from regional curves for the eastern United States. 


\section{Conversion Factors, Datums, and Abbreviated Units} of Measure

\begin{tabular}{|c|c|c|}
\hline Multiply & By & To obtain \\
\hline \multicolumn{3}{|c|}{ Length } \\
\hline inch (in.) & 2.54 & centimeter $(\mathrm{cm})$ \\
\hline foot $(\mathrm{ft})$ & 0.3048 & meter $(\mathrm{m})$ \\
\hline mile (mi) & 1.609 & kilometer $(\mathrm{km})$ \\
\hline \multicolumn{3}{|c|}{ Area } \\
\hline square foot $\left(\mathrm{ft}^{2}\right)$ & 0.09290 & square meter $\left(\mathrm{m}^{2}\right)$ \\
\hline square mile $\left(\mathrm{mi}^{2}\right)$ & 2.590 & square kilometer $\left(\mathrm{km}^{2}\right)$ \\
\hline
\end{tabular}

Horizontal coordinate information is referenced to the North American Datum of 1983 (NAD 83).

Elevation, as used in this report, refers to distance above or below a local arbitrary vertical datum established only for the purposes of this study.

\section{Other Abbreviations}

Additional abbreviations and acronyms used in this report:

ABF bankfull-channel cross-sectional area

DA drainage area

DBF mean bankfull-channel depth

FEH fluvial erosion hazard

GOF goodness of fit

GPS global positioning system

IUPUI Indiana University-Purdue University at Indianapolis

USGS U.S. Geological Survey

WBF bankfull-channel width 


\section{Acknowledgments}

This report is part of a larger effort to develop a fluvial erosion hazard (FEH) mitigation program for Indiana. Funding for the FEH program and this investigation has been provided by the Indiana Office of Community and Rural Affairs. I would like to thank Kathleen Weissenberger (Indiana Office of Community and Rural Affairs) and the Indiana Silver Jackets for their continued support of the FEH effort.

Bob Barr, Mike Stouder (both of the Indiana University-Purdue University at Indianapolis [IUPUI], Center for Earth and Environmental Science), and Matt Riggs (IUPUI, The Polis Center) provided key input when establishing field protocols and assisted with data collection at many sites. John Davis and John Bacone (both of the Indiana Department of Natural Resources) were instrumental in facilitating site access. Richard Williams and Scott McGarvie (both of Peabody Energy) provided valuable local knowledge regarding the stream channels of southwestern Indiana. The author gratefully acknowledges all of these individuals for the contributions they made to this investigation.

Jacqueline Cummins (U.S. Geological Survey) graciously endured swarming insects, quicksand, and record heat, all in the interest of establishing the best possible channel-dimension dataset. Thank you, Jackie, for your tremendous support through all phases of data collection and processing.

Finally, I would like to acknowledge Dr. Dale F. Ritter (Dusty) posthumously for his contributions to this effort. His guidance and wisdom profoundly influenced my understanding of geomorphic processes, the natural forces that shape streams, and the proper way to tell this story. 


\title{
Regional Bankfull-Channel Dimensions of Non-Urban Wadeable Streams in Indiana
}

\author{
By Bret A. Robinson
}

\section{Abstract}

During floods, damage to properties and community infrastructure may result from inundation and the processes of erosion. The damages imparted by erosion are collectively termed the fluvial erosion hazard (FEH), and the Indiana Silver Jackets Multi-agency Hazard Mitigation Taskforce is supporting a program to build tools that will assist Indiana property owners and communities with FEH-mitigation efforts. As part of that program, regional channel-dimension relations are identified for non-urban wadeable streams in Indiana.

With a site-selection process that targeted the three largest physiographic regions of the state, field work was completed to measure channel-dimension and channel-geometry characteristics across Indiana. In total, 82 sites were identified for data collection; 25 in the Northern Moraine and Lake region, 31 in the Central Till Plain region, and 26 in the Southern Hills and Lowlands region.

Following well established methods, for each data-collection site, effort was applied to identify bankfull stage, determine bankfull-channel dimensions, and document channelgeometry characteristics that allowed for determinations of channel classification. In this report, regional bankfull-channel dimension results are presented as a combination of plots and regression equations that identify the relations between drainage area and the bankfull-channel dimensions of width, mean depth, and cross-sectional area.

This investigation found that the channel-dimension data support independent relations for each of the three physiographic regions noted above. Furthermore, these relations show that, for any given drainage area, northern Indiana channels have the smallest predicted dimensions, southern Indiana channels have the largest predicted dimensions, and central Indiana channels are intermediate in their predicted dimensions. When considering the suite of variables that influence bankfull-channel dimensions, it appears that contrasting runoff characteristics between the three physiographic regions may explain much of the inequality observed in the measured channel dimensions. While this investigation targeted nonurban wadeable streams in Indiana, site conditions prevented data collection in some areas. Therefore, application of the results of this study always should include knowledge gained from local observations.

\section{Introduction}

Between 2006 and 2008, nearly all regions of Indiana were impacted by damaging floods. From this period of repeated flooding, 82 of the state's 92 counties received at least one disaster declaration for documented flood impacts and these counties became eligible for some assistance due to their sustained losses. While inundation by flood waters resulted in significant damages for many individual property owners and communities, the most costly and long-lasting damages often were brought about by processes of erosion: the undermining of roadways, bridge-supporting elements, residential structures, and public assets; the catastrophic failure or filling of culverts; the loss of agricultural land; and interruptions to traffic flow and emergency services (Morlock and others, 2008). The damages imparted by erosion and stream-channel migration processes are collectively termed the fluvial-erosion hazard (FEH).

At the same time that the 2006 to 2008 flood damages were being documented, a new consortium of Federal and State agencies - the Indiana Silver Jackets Multi-agency Hazard Mitigation Taskforce - was being formed. A fundamental goal of the Silver Jackets team is to identify and support efforts that could reduce costs associated with natural hazards and promote hazard mitigation. By the fall of 2010, the Silver Jackets team identified a series of science-based tools that could be assembled to help communities reduced their FEH risks. One of the identified tools was regional bankfull-channel-dimension curves for Indiana streams. 


\section{Basis of Regional Curves}

A fundamental concept within the field of fluvial geomorphology is that, as one moves downstream within a watershed, there is a predictable and quantifiable rate of increase in bankfull-channel dimensions. The early efforts to describe and document this concept can largely be attributed to three interrelated documents-Emmett and Leopold, 1963; Leopold, and others, 1964; and Dunne and Leopold, 1978. (For a more complete discussion of the historical development of this concept, the reader is directed to Emmett, 2004.) These three documents present results for four distinct regions - the San Francisco Bay region of California, the Upper Green River of Wyoming, the Upper Salmon River of Idaho, and the Eastern United States - and ultimately led to the recognition that downstream bankfull-channel-dimension increases are significantly influenced by geologic, climatic, and land-use controls.

In the initial work described above, and in numerous related papers that have followed, the means to predict bankfull-channel dimensions typically are presented as a combination of plots - commonly referred to as regional curves - and regression equations. Both of these tools are used to show the relation between drainage area and some desired channel dimension (for example: width of the bankfull channel, mean depth of the bankfull channel, and(or) cross-sectional area of the bankfull channel). These relations are established by collecting bankfull-channel-dimension data at stable sites that span a broad range of drainage areas and applying simple regression techniques to determine the best fit lines and their corresponding equations.

Where they are available, regional channel-dimension curves can be applied in a variety of engineering, streamrestoration, and floodplain-management activities to aid in field verification of bankfull-channel dimensions and to provide general descriptive and interpretive parameters. In the engineering realm, regional curves aid in sizing bridges and culverts and the placement of roadways and buried infrastructure. In stream-restoration activities, regional curves provide a range of target dimensions that assist in verification of field-identified bankfull-channel features; these verified fieldidentified features, in turn, provide appropriate dimensions as required for commonly applied natural-channel-design techniques. Regional curves also allow for the identification of stream reaches that depart significantly from their expected bankfull-channel-dimension values. For sound floodplain management, and in particular FEH-mapping applications, predictions of bankfull-channel dimensions are key to identifying zones where fluvial erosion may threaten existing or planned buildings or infrastructure (Vermont Agency of Natural Resources, 2009b).

Prior to the effort described in this report, regional bankfull-channel-dimension curves and the associated regression equations had not been published for a dataset collected from Indiana streams. Therefore, when predicted bankfull-channel dimensions were desired for Indiana waterways, regional curves and equations developed for other geographic areas were required as substitutes to generate estimated channeldimension values.

\section{Focus on Ungaged Sites}

Many previously published bankfull-channel-dimension studies (Harman and others, 1999; White, 2001; McCandless and Everett, 2002; Cinotto, 2003; Sherwood and Huitger; 2005; and Mistak and Stille, 2008) have focused their data collection at sites where the U.S. Geological Survey (USGS) has operated a streamgage and established a long-term record of streamflow-herein referred to as gaged sites. This approach has both advantages and disadvantages when compared to studies that include data collection at ungaged sites. In terms of an advantage, collecting channel-dimension data at gaged sites allows one to determine if bankfull stage identified in the field is confirmed by streamflow-discharge data; many hold that bankfull stage is associated with a discharge that is equaled or exceeded every 1 to 2 years (Wolman and Miller, 1960; Dunne and Leopold, 1978). By focusing data collection at gaged sites, some investigators have found a means for independent confirmation of the bankfull stages they identify using commonly applied field indicators.

At the same time, limiting data collection to gaged sites greatly restricts the range of some site characteristics. For example, in Indiana approximately 5 percent of active and discontinued USGS streamgages have been established at sites with drainage areas less than $5 \mathrm{mi}^{2}$ (Scott E. Morlock, U.S. Geological Survey-Indiana Water Science Center, oral commun., 2010). Because historically there has been very limited bankfull-channel-dimension data derived from sites with drainage areas less than $5 \mathrm{mi}^{2}$ and because most anthropogenic channel alterations are made to sites with small drainage areas, this investigation focused data collection at ungaged sites. By not restricting data-collection activities to gaged sites, a robust dataset was developed and it included a significant amount of data obtained from sites with relatively small drainage areas.

\section{Purpose and Scope}

This report presents methods and results of a geomorphic investigation to document bankfull-channel dimensions for non-urban wadeable streams in Indiana. The methods section presents the criteria used in the site-selection process, field techniques used to identify bankfull stage, and methods employed to measure channel-dimension, -geometry, and sediment-size characteristics for each study site included in this investigation. The section on bankfull-channel-dimensions describes the data analysis process and presents the relations discovered between drainage area and bankfull-channel width, mean depth, and cross-sectional area for three distinct physiographic regions of Indiana. This section also 
discusses one of the variables that may contribute to the observed relations and limitations that should be considered when applying the study results.

\section{Methods of Study}

When completing geomorphic investigations along natural channels, modern-day researchers are fortunate to have available numerous sources that present well documented techniques for data collection and analysis. Data-collection methods used in this investigation were, for the most part, selected from Harrelson and others (1994), Powell and others (2003), Rosgen (1996), and the U.S. Department of Agriculture (2003). Data analysis and presentation methods benefited from the published results of Montgomery and Buffington (1993), Harman and others (1999), White (2001), McCandless and Everett (2002), Cinotto (2003), Lawlor (2004), Sherwood and Huitger (2005), and Mistak and Stille (2008).

The sections that follow describe methods applied when activities were undertaken to document bankfull-channel dimensions and identify the channel type for each reach where data were collected. In most cases these methods were applied in the field; however, for some data elements (for example the measurement of channel sinuosity at relatively large sites) it was more appropriate to use map or aerial-photographic resources for data acquisition.

From the initial phases of study design and data collection, it was recognized that no two field sites are alike and that, in order to produce a high-quality channel-dimension dataset, the study design needed to incorporate consistent and repeatable field methods. The difficulty of accurately determining bankfull stage in the field has been discussed by many (Williams, 1978; Johnson and Heil, 1996; Juracek and Fitzpatrick, 2003), and Roper and others (2008) demonstrated that inconsistencies between field crews can lead to disparity for channel-classification results. While every attempt was made to minimize these potential inconsistencies, it is acknowledged that these difficulties are real and that, to some unknown extent, the data and results presented herein are influenced by these inherent errors.

\section{Site-Selection Criteria}

The Physiographic Divisions of Indiana report, authored by Gray (2000), presents a two-tiered system for discussing the areas of Indiana with distinct physiographic characteristics. His coarsest tier of distinction divides the state into four regions; the Northern Moraine and Lake region; the Maumee Lake Plain region, the Central Till Plain region, and the Southern Hills and Lowlands region (fig. 1). In turn, Gray divides three of his four regions into smaller divisions (or sections) where he discusses local characteristics and the details that allow for distinctions at a finer level of resolution. In this channel-dimension report, the discussions of physiographic regions refer to Gray's coarsest tier, and based on its limited size and description, for this report the Maumee Lake Plain region is grouped with the Northern Moraine and Lake region.

To identify bankfull-channel-dimension relations for any area, it is desirable to develop a dataset collected at widely distributed sites. With a multiple-decade history of working in Indiana streams and a review of Gray's (2000) Physiographic Divisions of Indiana, it was anticipated that measured bankfull-channel dimensions might vary from north to south and between physiographic regions. Therefore, from the outset of this investigation, the site-selection process was developed as a stratified sample design that tried to include a roughly equal number of sites from the Northern Moraine and Lake region, the Central Till Plain region, and the Southern Hills and Lowlands region.

With an initial minimum target of 72 sites for data collection, the site-selection process tried to identify at least 24 sites within each of these three physiographic regions. (The only physiographic section intentionally excluded from data collection was the Mitchell Plateau, which is an area characterized by extensive karst development. In karst landscapes, variable underground water-flow pathways preclude accurate determinations of drainage area for any given stream reach.)

When developing regional bankfull-channel-dimension curves, it also is desirable to build a dataset that includes sites spanning a broad range of drainage areas. Because this investigation focused on wadeable streams, it was anticipated that data collection would be completed at sites with drainage areas ranging from less than $1 \mathrm{mi}^{2}$ to approximately $200 \mathrm{mi}^{2}$. However, because Indiana experienced drought conditions during the 2011 and 2012 field seasons, data collection by wading was possible and completed at several sites with drainage areas greater than $200 \mathrm{mi}^{2}$.

To facilitate site access and establish a dataset from the most natural-least disturbed - stream reaches in Indiana, the site-selection process focused on protected lands in generally rural settings. These areas included: Hoosier National Forest, Indiana Dunes National Lakeshore, and Big Oaks National Wildlife Refuge; Indiana state parks, forests, nature preserves, and fish and wildlife management areas; large military holdings; county and municipal parks; and regional land trusts. After identifying potential data-collection sites using online aerial-photographic imagery, reconnaissance visits were undertaken to determine if sites were accessible, the channel and its banks appeared to be stable, and there was sufficient field evidence to make a confident determination of bankfull stage. 


\section{EXPLANATION}

Physiographic regions of Indiana

Northern Moraine and Lake

Maumee Lake Plain

Central Till Plain

Southern Hills and Lowlands

Names and shading patterns on the map identify the physiographic sections presented in Gray (2000).

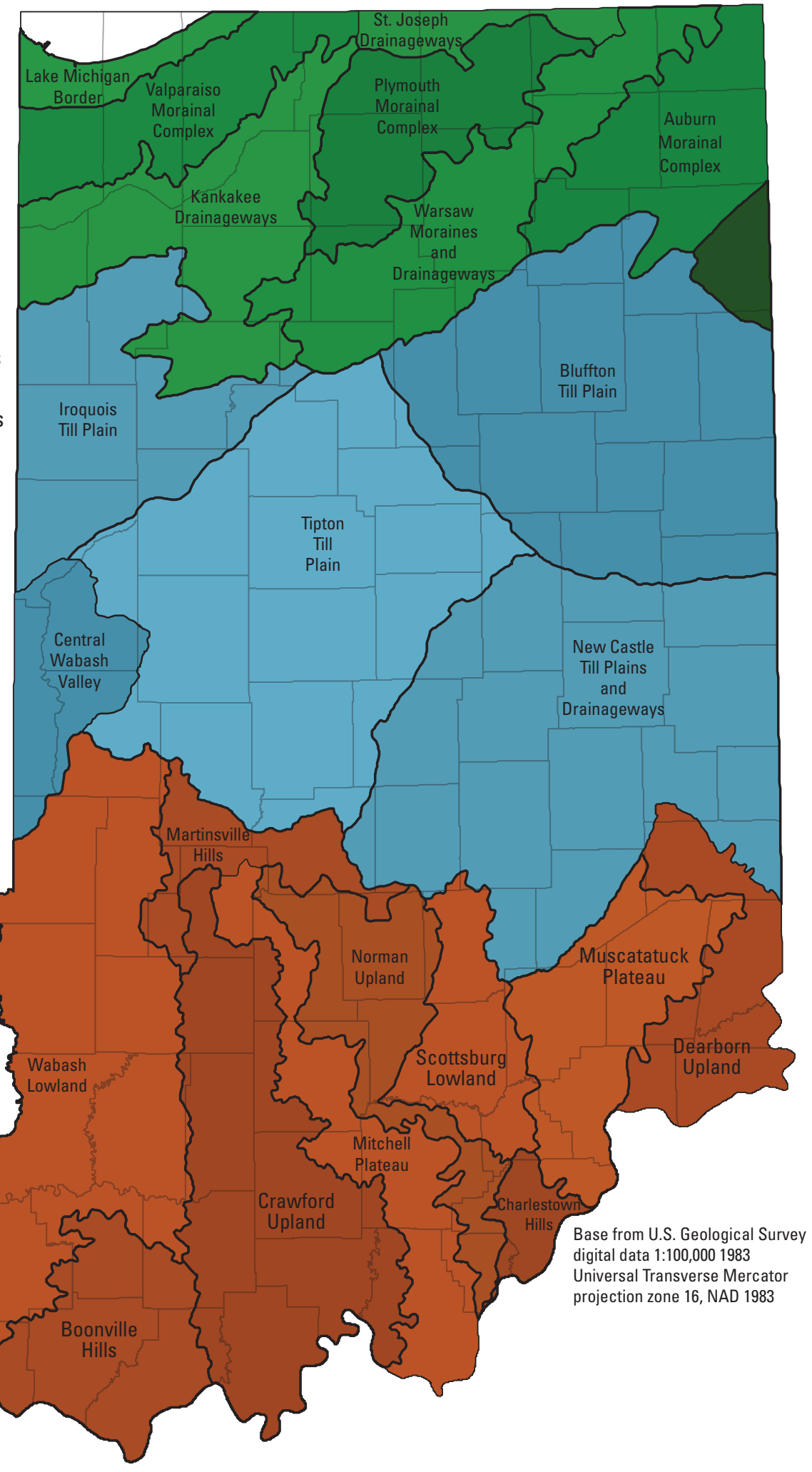

Figure 1. Physiographic regions and sections of Indiana. 


\section{Identification of Bankfull Stage}

Accurately identifying bankfull stage is essential where meaningful determinations of bankfull-channel dimensions are to be completed. Because proper identification and understanding of bankfull stage is vital to channel-restoration and -management activities, the interested reader is encouraged to study some of the numerous resources that are available for this subject: Harrelson and others (1994), Rosgen (1996), U.S. Department of Agriculture (2003), and Vermont Agency of Natural Resources (2009a).

In this investigation, when a site was first visited, the field crew walked the study reach and searched for reliable field indicators of bankfull stage. For most sites, this search was carried out over a channel length approximately equal to 20 times the bankfull-channel width. During these activities, most time and effort was applied at the inside of meander bends and along straight channel reaches; at these locations, field indicators of bankfull stage have the greatest opportunity to develop and be preserved.

The available literature describes numerous channel-side features that may be observed in the field to aid in identifying bankfull stage. These include the elevation of the adjacent floodplain, the level top of point bars, breaks in channel-bank slopes, changes in vegetation, scour lines, and changes in sediment-size characteristics. A U.S. Department of Agriculture (2003) video-A Guide to Identification of Bankfull Stage in the Northeastern U.S. - discusses some of the fundamental science aspects of bankfull stage and the bankfull channel. In that video presentation, on-camera narrators visit several locations to illustrate some of the field indicators that may be observed when one sets out to use geomorphic evidence to identify bankfull stage in the field.

In this effort to document bankfull-channel dimensions for Indiana streams, the methods and field indicators recommended by the U.S. Department of Agriculture (2003) video were adopted as fundamental to our study design and field approach. Also, in efforts to foster consistency between sites and the proper identification of bankfull stage at all sites, (1) the author participated in all data-collection activities at all sites, (2) there was a consistency of USGS field personnel throughout the duration of our field activities, (3) photographs from all field sites were shared and discussed with other experienced researchers, and (4) many field sites were visited by local researchers experienced with Indiana streams.

In the investigation described herein, three field indicators of bankfull stage were found to be the most frequently observed and reliable: the lowest horizontal tread of the floodplain adjacent to the active channel, the location and form of channel-side trees, and a transition to all sand deposition in overbank locations. At all field sites selected for data collection, multiple examples of these and other field indicators of bankfull stage were sought to confirm the identified bankfull elevation.
At most sites where it was possible to identify bankfull stage with confidence, one could walk up the slope of the channel bank, step just beyond the active channel, and find a location where one's foot would rest on the lowest horizontal tread of the active floodplain. An example of this can be seen in figure $2 A$. At this location, the right foot of the investigator remains on the slope of the channel bank, while her left foot rests on the horizontal tread of the local floodplain. For many data-collection sites, the channel-side edge of this lowest horizontal surface was the single most frequently observed and utilized field indicator of bankfull stage.

In forested settings of the eastern United States, trees tend to grow on the fluvial plain and up to the boundary that separates the fluvial plain from the active channel; however, trees generally do not become established within the active channel (U.S. Department of Agriculture, 2003). During field activities it was consistently observed that trees growing within the boundaries of the active channel exhibit a growth form that divulges their location within the active channel, and from this growth form one can deduce a portion of the life history of these trees.

We consistently observed that the vast majority of trees growing within the active channel, and below the elevation of bankfull stage, had curved trunks just above their root collars (fig. $2 B$ ). In these settings, one could deduce that the trees had originally grown on the fluvial plain adjacent to the active channel. Then, channel-migration processes had caused the trees to lean toward the active channel as they slowly were undercut by erosion of the channel bank. Because trees are phototropic, with time they adjust their growth form to seek their overhead light source. As this process continues slowly over years, trees that have been undercut by bank erosion exhibit a distinctly curved trunk just above their root collar. During field activities, when trees with curved trunks were observed, it was learned that one needed to look to a slightly higher elevation than the root collar if bankfull stage was to be identified.

The third field indicator of bankfull stage that significantly contributed to the investigation's field efforts was the identification of well sorted sand deposits just beyond the boundary of the active channel (fig. $2 C$ ). For most sites where data collection was completed, the bedload material observed in the active channel was a poorly sorted mixture of sand, gravel, and in some locations cobbles. During high-streamflow periods, this entire mixture of sediment may become mobile within the active channel; however, it is generally only the sand fraction of this mixture that is carried beyond the boundaries of the active channel and deposited in channel-side locations. Where they could be found, the channel-side edge of these sand deposits often helped in the identification of bankfull stage. In the rare cases when a site was visited shortly after a period of flooding, these sand deposits often were readily observed; however, at most sites these sand deposits only were identified after some effort to expose them from under the vegetation and leaf litter that covered the active floodplain. 

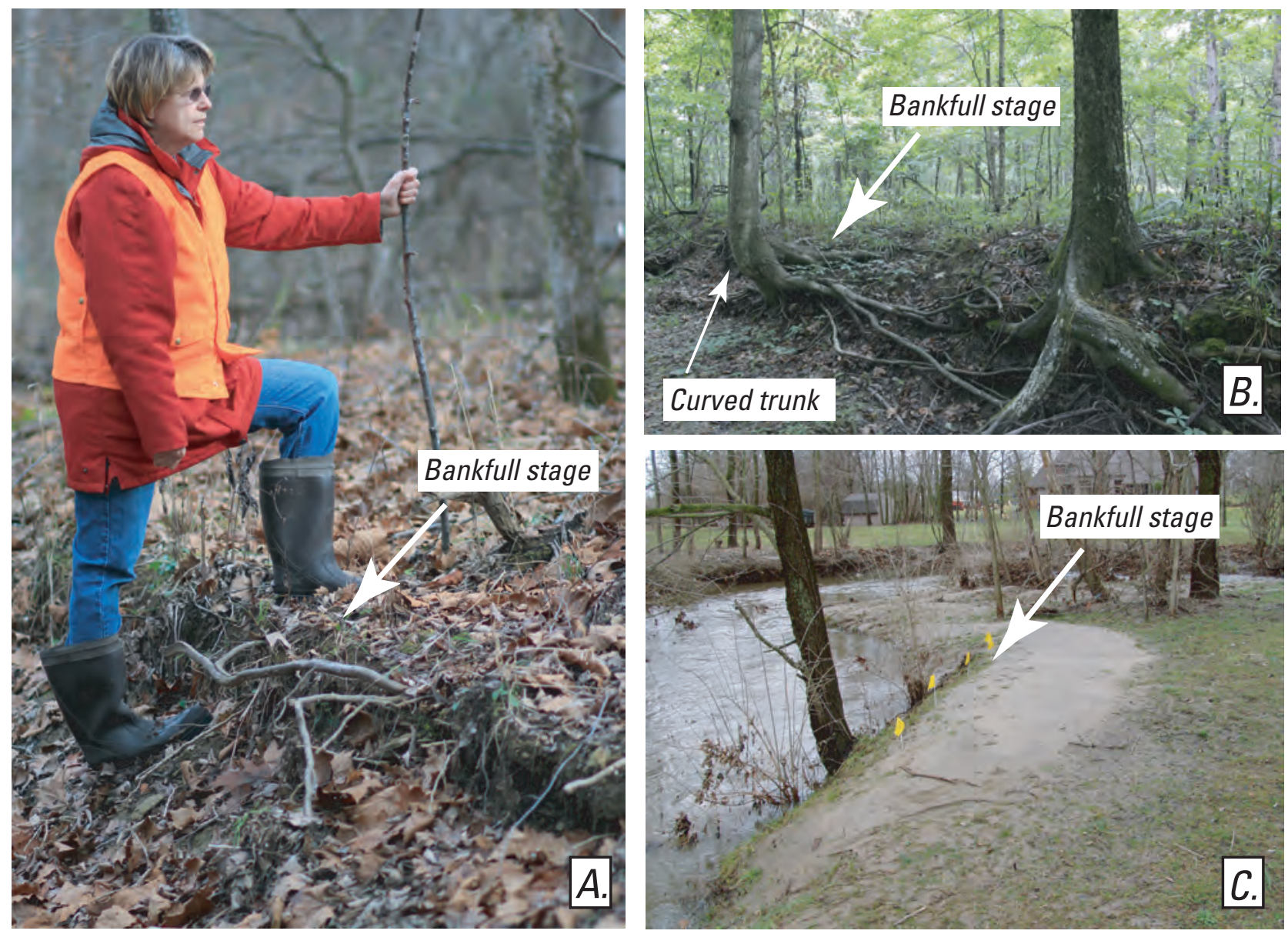

Figure 2. The three most frequently observed field indicators of bankfull stage.

While first working at a site and trying to determine if a consistent elevation of bankfull stage could be identified, the field crew walked the study reach and flagged those locations where field indicators of bankfull stage were observed. Then, along with capturing photographic records, field observations of topographic, vegetative, and sediment-texture characteristics were recorded and a bankfull-stage determination was made. Only those sites that produced a confident determination of bankfull stage were selected for inclusion in this study.

At those sites where a consistent elevation of bankfull stage was identified, a single representative channel cross section was selected for the measurement of channel-dimension data. The cross sections selected for data collection targeted locations where the observed channel width was representative of the entire study reach; typically at or very near a riffle and in a generally straight channel segment.

\section{Site Identification and Location}

Because this investigation was attempting to collect channel-dimension data from a roughly equal number of sites in the three broadest physiographic regions of Indiana, a site-identification system based on these three regions was established and applied. In this system, sites in the Northern Moraine and Lake region were sequentially numbered beginning with RC-100, sites in the Central Till Plain region were sequentially numbered beginning with RC-200, and sites in the Southern Hills and Lowlands region were sequentially numbered beginning with RC-300. This site-identification system did not influence the data-analysis process; any desired grouping of data could be completed regardless of site number. This site-identification system simply allowed for an easy recognition of the number of sites measured in each of the three physiographic regions. Figure 3 shows the location of each data-collection site and places them within the physiographic boundaries shown in figure 1. In total, data-collection activities were completed at 82 sites statewide; 25 sites were in the Northern Moraine and Lake region, 31 in the Central Till Plain region, and 26 in the Southern Hills and Lowlands region.

A handheld global positioning system (GPS) unit with an approximate 20 -ft horizontal accuracy was used to document the location of each measurement cross section. Additional site-identification data - county name and stream name - also were recorded and are presented in table 1. 


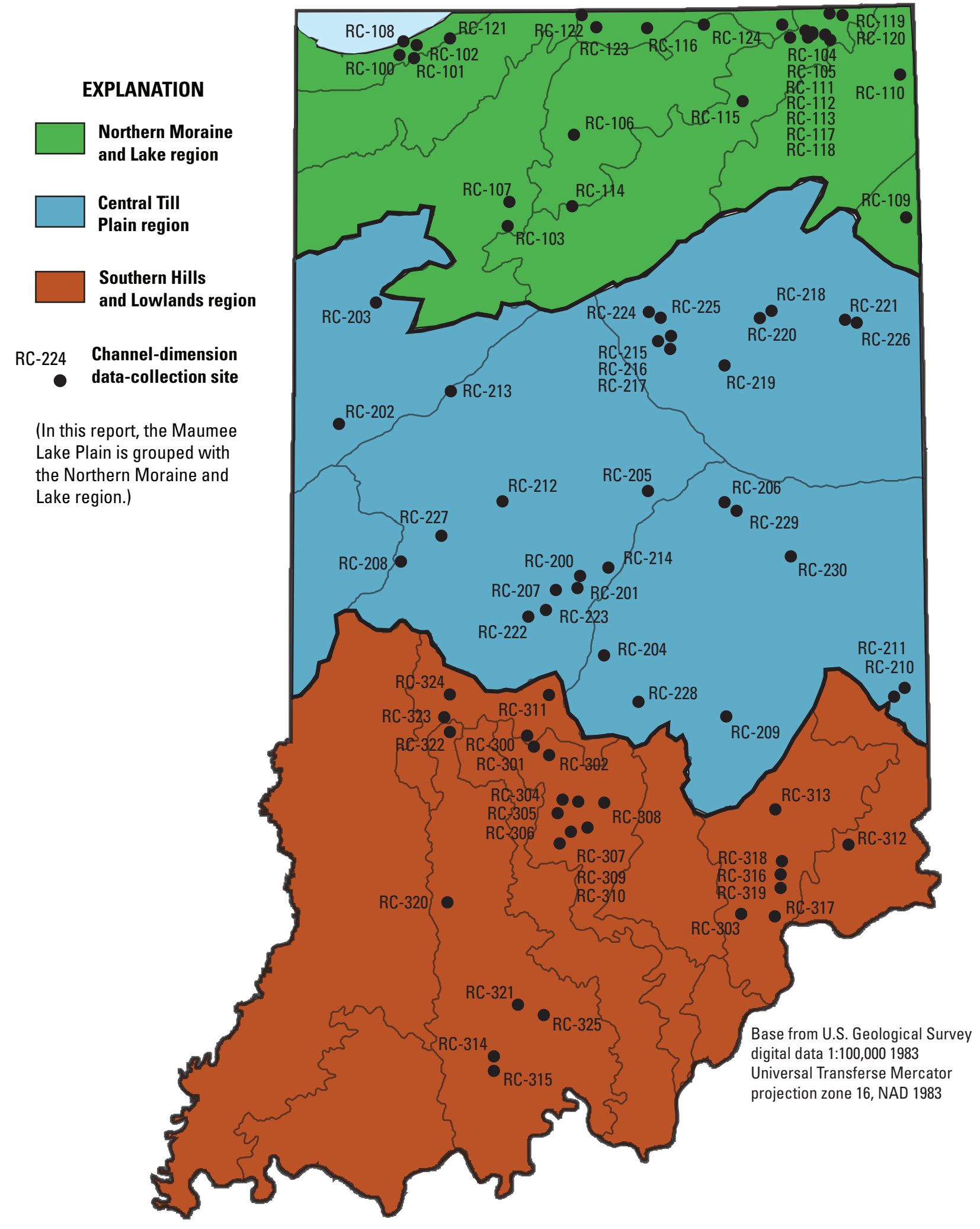

Figure 3. Location of the 82 sites where bankfull-channel-dimension data were collected in Indiana. 
Table 1. Location information for the 82 sites where data were collected to document bankfull-channel dimensions of non-urban wadeable streams in Indiana.

\begin{tabular}{|c|c|c|c|c|}
\hline $\begin{array}{c}\text { Site } \\
\text { identifier }\end{array}$ & Stream name & County & $\begin{array}{c}\text { Latitude } \\
\text { (degrees north) }\end{array}$ & $\begin{array}{c}\text { Longitude } \\
\text { (degrees west) }\end{array}$ \\
\hline $\mathrm{RC}-100$ & Dunes Creek & Porter & $41.65963^{\circ}$ & $87.05952^{\circ}$ \\
\hline RC-101 & West Branch Trail Creek & LaPorte & $41.67324^{\circ}$ & $86.84835^{\circ}$ \\
\hline $\mathrm{RC}-102$ & Unnamed tributary to Munson Ditch & Porter & $41.64473^{\circ}$ & $87.03922^{\circ}$ \\
\hline $\mathrm{RC}-103$ & Dilts Anstis Ditch & Pulaski & $41.13365^{\circ}$ & $86.59145^{\circ}$ \\
\hline RC-104 & Turkey Creek & Lagrange & $41.66350^{\circ}$ & $85.27290^{\circ}$ \\
\hline $\mathrm{RC}-105$ & Bloody Run & Lagrange & $41.67418^{\circ}$ & $85.25302^{\circ}$ \\
\hline $\mathrm{RC}-106$ & Unnamed tributary to Yellow River & Marshall & $41.35350^{\circ}$ & $86.30513^{\circ}$ \\
\hline $\mathrm{RC}-107$ & Tippecanoe River & Pulaski & $41.05228^{\circ}$ & $86.59711^{\circ}$ \\
\hline $\mathrm{RC}-108$ & Dunes Creek & Porter & $41.65683^{\circ}$ & $87.05786^{\circ}$ \\
\hline RC-109 & West Branch Fish Creek & Steuben & $41.06270^{\circ}$ & $84.85790^{\circ}$ \\
\hline $\mathrm{RC}-110$ & Fish Creek & Steuben & $41.53268^{\circ}$ & $84.86885^{\circ}$ \\
\hline $\mathrm{RC}-111$ & Crooked Creek & Steuben & $41.73478^{\circ}$ & $85.11887^{\circ}$ \\
\hline $\mathrm{RC}-112$ & Fawn River & Steuben & $41.74150^{\circ}$ & $85.17490^{\circ}$ \\
\hline $\mathrm{RC}-113$ & Pigeon Creek & Steuben & $41.67095^{\circ}$ & $85.19530^{\circ}$ \\
\hline $\mathrm{RC}-114$ & Tippecanoe River & Fulton & $41.11780^{\circ}$ & $86.31418^{\circ}$ \\
\hline $\mathrm{RC}-115$ & Elkhart River & Noble & $41.45731^{\circ}$ & $85.56543^{\circ}$ \\
\hline $\mathrm{RC}-116$ & Little Elkhart River & Elkhart & $41.71085^{\circ}$ & $85.72884^{\circ}$ \\
\hline $\mathrm{RC}-117$ & Pigeon River & Lagrange & $41.70690^{\circ}$ & $85.38350^{\circ}$ \\
\hline $\mathrm{RC}-118$ & Pigeon River & Lagrange & $41.68683^{\circ}$ & $85.28208^{\circ}$ \\
\hline RC-119 & Pigeon Creek & Lagrange & $41.67813^{\circ}$ & $85.25349^{\circ}$ \\
\hline $\mathrm{RC}-120$ & Pigeon Creek & Steuben & $41.65139^{\circ}$ & $85.17424^{\circ}$ \\
\hline $\mathrm{RC}-121$ & Munson Ditch & Porter & $41.65637^{\circ}$ & $87.04851^{\circ}$ \\
\hline $\mathrm{RC}-122$ & Unnamed tributary to St. Joseph River & St Joseph & $41.74854^{\circ}$ & $86.26575^{\circ}$ \\
\hline $\mathrm{RC}-123$ & Juday Creek & St Joseph & $41.70667^{\circ}$ & $86.20503^{\circ}$ \\
\hline $\mathrm{RC}-124$ & Christiana Creek & Elkhart & $41.70108^{\circ}$ & $85.97973^{\circ}$ \\
\hline RC-200 & Crest Branch & Marion & $39.87328^{\circ}$ & $86.31056^{\circ}$ \\
\hline RC-201 & DeLong Creek & Marion & $39.85445^{\circ}$ & $86.31564^{\circ}$ \\
\hline RC-202 & Big Pine Creek & Warren & $40.40059^{\circ}$ & $87.32887^{\circ}$ \\
\hline RC-203 & Carpenter Creek & Jasper & $40.80081^{\circ}$ & $87.17146^{\circ}$ \\
\hline RC-204 & Pleasant Run & Johnson & $39.63340^{\circ}$ & $86.19308^{\circ}$ \\
\hline $\mathrm{RC}-205$ & Killbuck Creek & Madison & $40.13448^{\circ}$ & $85.66860^{\circ}$ \\
\hline RC-206 & Cicero Creek & Hamilton & $40.17455^{\circ}$ & $85.99806^{\circ}$ \\
\hline RC-207 & White Lick Creek & Hendricks & $39.84992^{\circ}$ & $86.39773^{\circ}$ \\
\hline RC-208 & Sugar Creek & Montgomery & $39.94516^{\circ}$ & $87.06145^{\circ}$ \\
\hline RC-209 & Conns Creek & Shelby & $39.42617^{\circ}$ & $85.67605^{\circ}$ \\
\hline $\mathrm{RC}-210$ & Unnamed tributary to Brookville Lake & Franklin & $39.48084^{\circ}$ & $84.96046^{\circ}$ \\
\hline RC-211 & Unnamed tributary to Brookville Lake & Franklin & $39.47907^{\circ}$ & $84.96328^{\circ}$ \\
\hline $\mathrm{RC}-212$ & Sugar Creek & Boone & $40.14423^{\circ}$ & $86.62525^{\circ}$ \\
\hline $\mathrm{RC}-213$ & Burnett Creek & Tippecanoe & $40.50702^{\circ}$ & $86.84550^{\circ}$ \\
\hline $\mathrm{RC}-214$ & Williams Creek & Marion & $39.92337^{\circ}$ & $86.17100^{\circ}$ \\
\hline $\mathrm{RC}-215$ & Unnamed tributary to Mississinewa Lake & Wabash & $40.67448^{\circ}$ & $85.89515^{\circ}$ \\
\hline
\end{tabular}


Table 1. Location information for the 82 sites where data were collected to document bankfull-channel dimensions of non-urban wadeable streams in Indiana.-Continued

\begin{tabular}{|c|c|c|c|c|}
\hline $\begin{array}{c}\text { Site } \\
\text { identifier }\end{array}$ & Stream name & County & $\begin{array}{c}\text { Latitude } \\
\text { (degrees north) }\end{array}$ & $\begin{array}{c}\text { Longitude } \\
\text { (degrees west) }\end{array}$ \\
\hline RC-216 & Liston Creek & Wabash & $40.67107^{\circ}$ & $85.92036^{\circ}$ \\
\hline $\mathrm{RC}-217$ & Unnamed tributary to Mississinewa Lake & Wabash & $40.68687^{\circ}$ & $85.93034^{\circ}$ \\
\hline $\mathrm{RC}-218$ & Brook Creek & Huntington & $40.74001^{\circ}$ & $85.50659^{\circ}$ \\
\hline $\mathrm{RC}-219$ & Mississinewa River & Grant & $40.58618^{\circ}$ & $85.66258^{\circ}$ \\
\hline $\mathrm{RC}-220$ & Salamonie River & Huntington & $40.74312^{\circ}$ & $85.50883^{\circ}$ \\
\hline $\mathrm{RC}-221$ & Wabash River & Wells & $40.72842^{\circ}$ & $85.13698^{\circ}$ \\
\hline $\mathrm{RC}-222$ & West Fork White Lick Creek & Hendricks & $39.76330^{\circ}$ & $86.51534^{\circ}$ \\
\hline $\mathrm{RC}-223$ & White Lick Creek & Hendricks & $39.75991^{\circ}$ & $86.41679^{\circ}$ \\
\hline $\mathrm{RC}-224$ & Mississinewa River & Miami & $40.72680^{\circ}$ & $86.00350^{\circ}$ \\
\hline $\mathrm{RC}-225$ & Unnamed tributary to Mississinewa River & Miami & $40.72542^{\circ}$ & $85.99890^{\circ}$ \\
\hline $\mathrm{RC}-226$ & Unnamed tributary to Wabash River & Wells & $40.72348^{\circ}$ & $85.12030^{\circ}$ \\
\hline $\mathrm{RC}-227$ & Dry Branch Creek & Montgomery & $40.03001^{\circ}$ & $86.88803^{\circ}$ \\
\hline $\mathrm{RC}-228$ & Hurricane Creek & Johnson & $39.47831^{\circ}$ & $86.04985^{\circ}$ \\
\hline $\mathrm{RC}-229$ & Bronnenberg Ditch & Madison & $40.10514^{\circ}$ & $85.61900^{\circ}$ \\
\hline $\mathrm{RC}-230$ & Unnamed tributary to Memorial Creek & Henry & $39.95138^{\circ}$ & $85.38841^{\circ}$ \\
\hline $\mathrm{RC}-300$ & Unnamed tributary to Bryant Creek & Monroe & $39.32310^{\circ}$ & $86.48410^{\circ}$ \\
\hline $\mathrm{RC}-301$ & Unnamed tributary to Bryant Creek & Monroe & $39.32866^{\circ}$ & $86.49898^{\circ}$ \\
\hline $\mathrm{RC}-302$ & Greasy Creek & Monroe & $39.29280^{\circ}$ & $86.43630^{\circ}$ \\
\hline $\mathrm{RC}-303$ & Big Creek & Jefferson & $38.79976^{\circ}$ & $85.61531^{\circ}$ \\
\hline $\mathrm{RC}-304$ & Unnamed tributary to Crooked Creek & Brown & $39.11369^{\circ}$ & $86.30732^{\circ}$ \\
\hline $\mathrm{RC}-305$ & Unnamed tributary to Crooked Creek & Brown & $39.11340^{\circ}$ & $86.30812^{\circ}$ \\
\hline $\mathrm{RC}-306$ & Strahl Creek & Brown & $39.14016^{\circ}$ & $86.21174^{\circ}$ \\
\hline $\mathrm{RC}-307$ & Unnamed tributary to Dry Branch & Brown & $39.14903^{\circ}$ & $86.30790^{\circ}$ \\
\hline RC-308 & Crooked Creek & Brown & $39.10964^{\circ}$ & $86.31317^{\circ}$ \\
\hline RC-309 & Dry Branch & Brown & $39.14706^{\circ}$ & $86.30677^{\circ}$ \\
\hline $\mathrm{RC}-310$ & Dry Branch & Brown & $39.15061^{\circ}$ & $86.30820^{\circ}$ \\
\hline $\mathrm{RC}-311$ & Unnamed tributary to Sycamore Creek & Morgan & $39.50398^{\circ}$ & $86.43002^{\circ}$ \\
\hline $\mathrm{RC}-312$ & Laughery Creek & Ripley & $38.99488^{\circ}$ & $85.16612^{\circ}$ \\
\hline $\mathrm{RC}-313$ & Muscatatuck River & Jennings & $39.11644^{\circ}$ & $85.47443^{\circ}$ \\
\hline RC-314 & Unnamed tributary to Anderson River & Crawford & $38.30915^{\circ}$ & $86.67017^{\circ}$ \\
\hline $\mathrm{RC}-315$ & Anderson River & Crawford & $38.30766^{\circ}$ & $86.67045^{\circ}$ \\
\hline $\mathrm{RC}-316$ & Big Creek & Jefferson & $38.89171^{\circ}$ & $85.46195^{\circ}$ \\
\hline $\mathrm{RC}-317$ & Herberts Creek & Jefferson & $38.78112^{\circ}$ & $85.50961^{\circ}$ \\
\hline $\mathrm{RC}-318$ & Marble Creek & Jefferson & $38.89962^{\circ}$ & $85.46262^{\circ}$ \\
\hline RC-319 & Middle Fork Creek & Jefferson & $38.85138^{\circ}$ & $85.46037^{\circ}$ \\
\hline RC-320 & Unnamed tributary to Boggs Creek & Martin & $38.81951^{\circ}$ & $86.86492^{\circ}$ \\
\hline $\mathrm{RC}-321$ & Unnamed tributary to French Lick Creek & Orange & $38.48137^{\circ}$ & $86.57059^{\circ}$ \\
\hline $\mathrm{RC}-322$ & Unnamed tributary to Rattlesnake Creek & Owen & $39.38697^{\circ}$ & $86.82717^{\circ}$ \\
\hline $\mathrm{RC}-323$ & Rattlesnake Creek & Owen & $39.39195^{\circ}$ & $86.83398^{\circ}$ \\
\hline $\mathrm{RC}-324$ & Unnamed tributary to Doe Creek & Putnam & $39.48255^{\circ}$ & $86.84801^{\circ}$ \\
\hline $\mathrm{RC}-325$ & Hogs Defeat Creek & Orange & $38.44680^{\circ}$ & $86.45953^{\circ}$ \\
\hline
\end{tabular}




\section{Bankfull-Channel Dimensions}

To measure bankfull-channel dimensions, a removable stake was placed in the ground at the location where bankfull stage was identified along the selected measurement cross section (fig. 4A). From this stake, a fiberglass measuring tape was oriented perpendicular to flow and extended to the opposite channel bank. All measurements of bankfull-channel dimensions were then completed along the line established by this fiberglass tape.

An optical level (fig. $4 B$ ) and stadia rod (fig. $4 C$ ) were used to project the elevation of the bankfull-stage-marker stake to the opposite channel bank and identify the location where bankfull stage would intersect that bank. Bankfullchannel-width measurements were completed by pulling the measuring tape tight along the established horizontal line and directly reading the tape to the nearest one-tenth of a foot. The optical level and stadia rod then were used to measure bankfull-channel depths at approximately 20 evenly spaced locations along the measurement cross section. In turn, these bankfull-depth measurements were used to calculate mean bankfull-channel depth and bankfull cross-sectional area. Bankfull-channel widths and mean bankfull-channel depths are reported in feet, while bankfull-channel cross-sectional areas are reported in units of square feet.

\section{Data Elements Required for Channel Classification}

In many scientific fields, classification systems group individuals by the common characteristics they share and attempt to identify order within observations made of a natural population. Following this desire to identify order, for more than a century stream-channel classification systems have been proposed: Davis (1899); Melton (1936); Leopold and Wolman (1957); Schumm (1963); Rosgen (1994).

Today, because many practitioners view the Rosgen channel classification system (Rosgen, 1996) as a beneficial communication tool, it is widely applied in discussions of channel-naturalization projects. To classify our field sites within the Rosgen system, additional data elements were required. These included channel slope, sinuosity, entrenchment ratio, width/depth ratio, and a measure of the dominant sediment size found in the bed material of each study site. The methods used to measure these parameters and make determinations of classification are presented below.

\section{Slope}

For sites where it was practical, channel slope was measured in the field and from a stream reach that extended approximately 10 to 20 times the measured bankfull-channel width. Working in an upstream direction, an optical level, stadia rod, and fiberglass measuring tape or electronic laser range finder were used to determine the amount of streambed rise over a measured length of channel. For the purposes of this study, it was determined that the most reliable and repeatable results were achieved from measurements that targeted the edge of water within the low-flow channel. For most sites, these data were collected as a series of measurements within the active channel.

For the largest sites, it was not practical to measure channel slope in the field. For these sites, online map resources (produced at a scale of 1:24,000) were used to identify where upstream and downstream contour lines crossed the mapped channel. Path-length tools then were used to measure the channel length between these contour crossings and a calculation of channel slope was completed.

\section{Sinuosity}

For each study site, channel sinuosity was determined following one of two methods. For large sites, where online aerial photographs with an appropriate level of detail were available, sinuosity was determined in the office. For these sites, fixed end points were identified and online tools were used to measure the channel length and valley length between the end points. For relatively small sites, where online resources did not provide a sufficient level of detail, sinuosity was measured in the field. At these sites, a fiberglass measuring tape or electronic laser rangefinder was used to measure the length of channel segments that followed the anticipated flow path of the active channel. The sum of these segments provided a measure of total channel length between identified end points. Then, working in the active channel and across the fluvial plain, a straight-line measurement was completed to determine the total valley length between these same two end points. For all sites, sinuosity was calculated as the ratio of channel length divided by valley length.

\section{Entrenchment Ratio}

Entrenchment ratio is a term used by Rosgen (1996) to express the relative change in water-surface width when a channel and attendant valley transition from bankfulldischarge conditions to substantial flooding. Calculation of entrenchment ratio is a multiple-step process (fig. 5). First, for a given cross section of interest, one must identify bankfull stage and measure the maximum water depth that would result from bankfull discharge. Then, this maximum water depth is doubled and measurements are completed to project how wide the water surface would be if there was discharge sufficient to produce the calculated water depth. In the Rosgen scheme, the portion of the valley bottom inundated by this hypothetical flood is referred to as the flood-prone area. Finally, entrenchment ratio is calculated by dividing the width of the floodprone area by the width of the bankfull channel.

During field activities, the width of the flood-prone area was determined after the 20 measurements of bankfullchannel depth had been completed along the bankfull-channel 


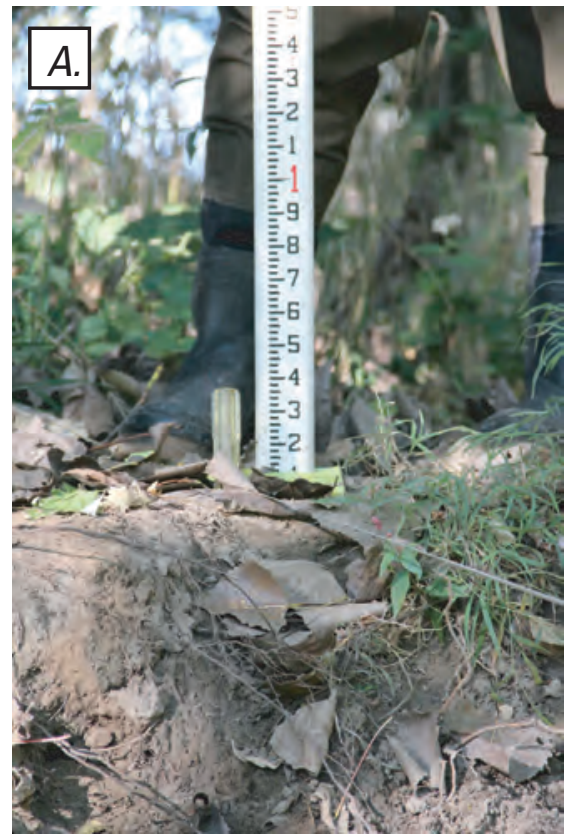

A removable stake was placed to mark the elevation of bankfull stage on the chosen measurement cross section.

An optical level (below) and stadia rod $\rightarrow$ were used to transfer the elevation of bankfull stage to the opposite bank.
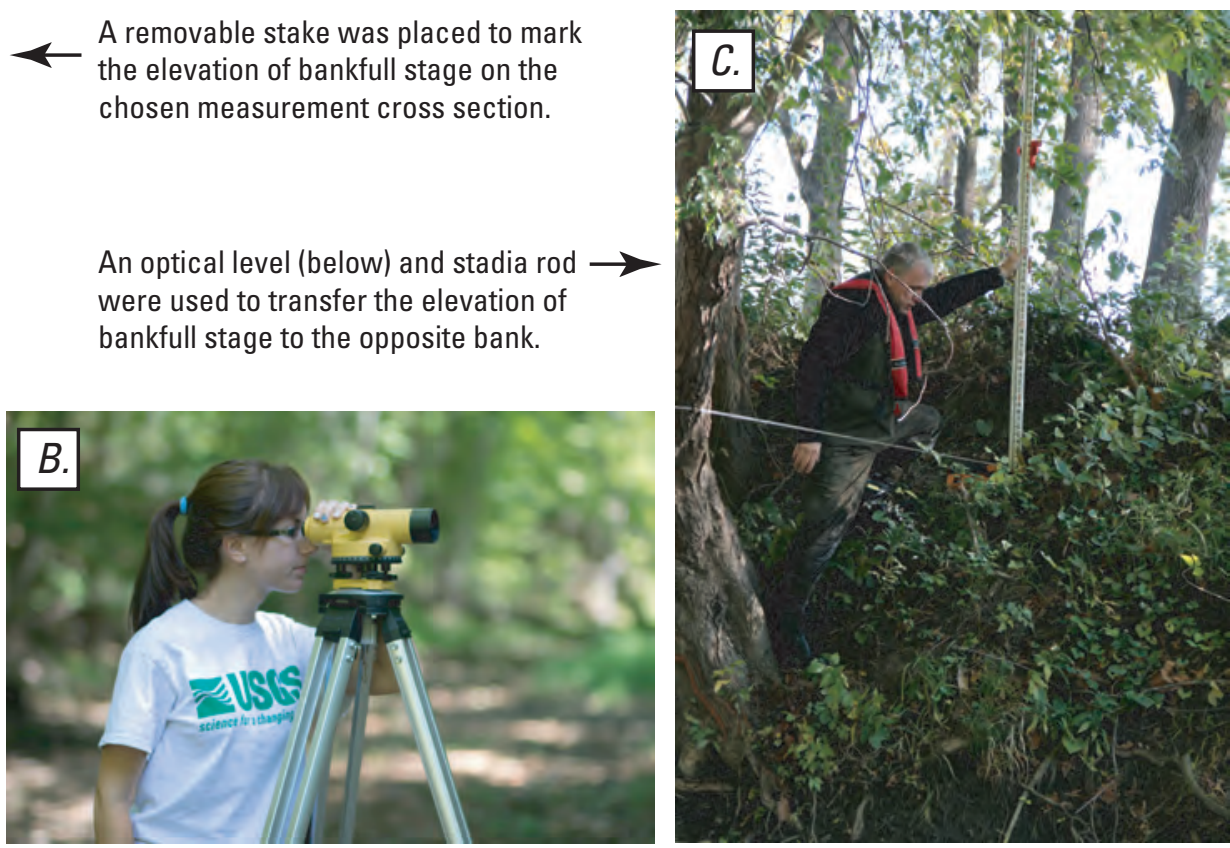

Figure 4. Photographs showing field activities to establish the boundaries of measurement cross-sections where bankfull-channeldimension data were collected.

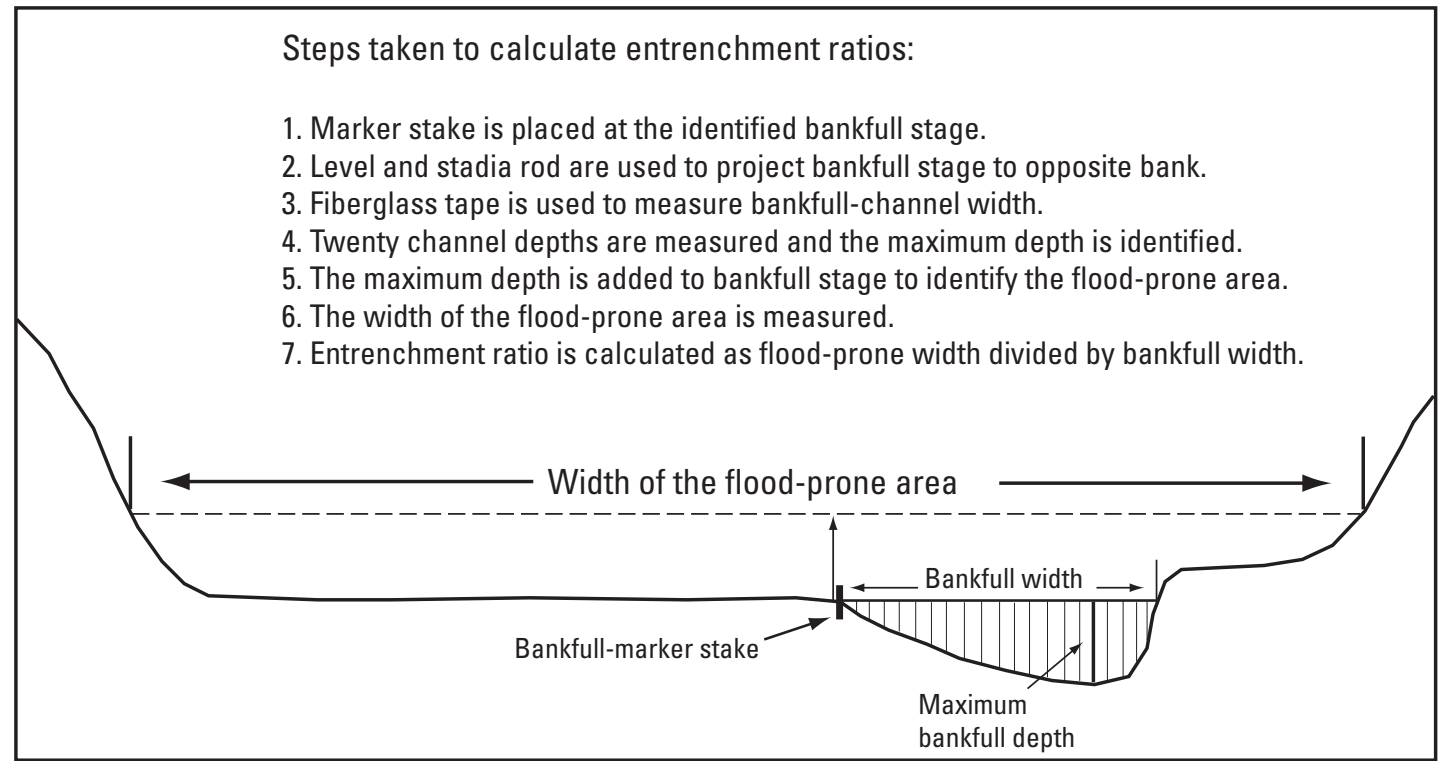

Figure 5. Steps taken to determine entrenchment ratios. measurement cross section. From these channel-depth measurements, the single largest depth value was identified and added to the elevation of bankfull stage at the bankfull-marker stake. Where it was practical, a fiberglass measuring tape or electronic laser range finder was used to measure the width of the projected flood surface. Where dense fluvial-plain vegetation or other obstructions made the use of these tools impractical, width of the flood-prone area was visually estimated.

\section{Width/Depth Ratio}

The width/depth ratio is calculated by dividing the bankfull-channel width by the mean bankfull-channel depth. This calculated value is unitless and is commonly used by geomorphologists as an expression of the general shape of the bankfull cross-channel profile; larger values describe relatively wide and shallow channels, while smaller values describe relatively narrow and deep channels. 


\section{Dominant Sediment Size of Bed Materials}

At each study site, one of two methods was employed to complete bed-material-size determinations. For sites where gravel and(or) cobbles represented a significant portion of the bed material, representative transects were identified where bed-material particles could be collected using a modified Wolman (1954) pebble count. A gravelometer (fig. 6) was then used to measure the intermediate axis of each collected particle and determine the sediment-size class most frequently observed in the channel bed material. For other sites, where the bed-material texture prevented the use of a gravelometer or water depths were too great for hand sampling, observations - visual and tactual — made during surveying activities were used to identify the dominant size class of the channelbed material.

\section{Rosgen Level II Classification}

Beginning with its introduction in the mid-1990s, the Rosgen channel-classification system has been the focus of a spirited debate in modern geomorphic literature. Whereas many will describe the classification system as a useful communication tool, others (Miller and Ritter, 1996; Juracek and Fitzpatrick, 2003; Simon and others, 2005) have been very critical of its form-based approach to process-based systems. And while it is well beyond the purpose or scope of this investigation to contribute to this debate, it does seem appropriate, in the interest of completeness, to include level II classification results where they can be established.

The Rosgen level II classification results presented herein were derived by applying the criteria given in figure 5-3 of the Rosgen (1996) text. In that figure, classification-defining ranges for entrenchment ratio, width/depth ratio, and sinuosity are presented in table format to guide the classification process. It is important to note that this figure also includes a statement, given in the key below the table, that broadens the range of values presented in the table. This statement reads, "...entrenchment and sinuosity ratios can vary by $+/-0.2$ units; while values for width/depth ratios can vary by $+/-2.0$ units." In this investigation, when attempting to classify each study reach within the Rosgen (1996) scheme, site data were evaluated against the broadest criteria ranges derived from the Rosgen figure 5-3 table and attendant key.

For most study sites, it was found that a single stream type (or class) could be identified from the class-defining criteria and that the site characteristics viewed in the field agreed well with the descriptions and images presented by Rosgen (1996). However, for 24 of the 82 study sites, it was found that the site-geometry data (1) did not match any of the Rosgen classes, (2) produced ambiguous results, or (3) fit the defining

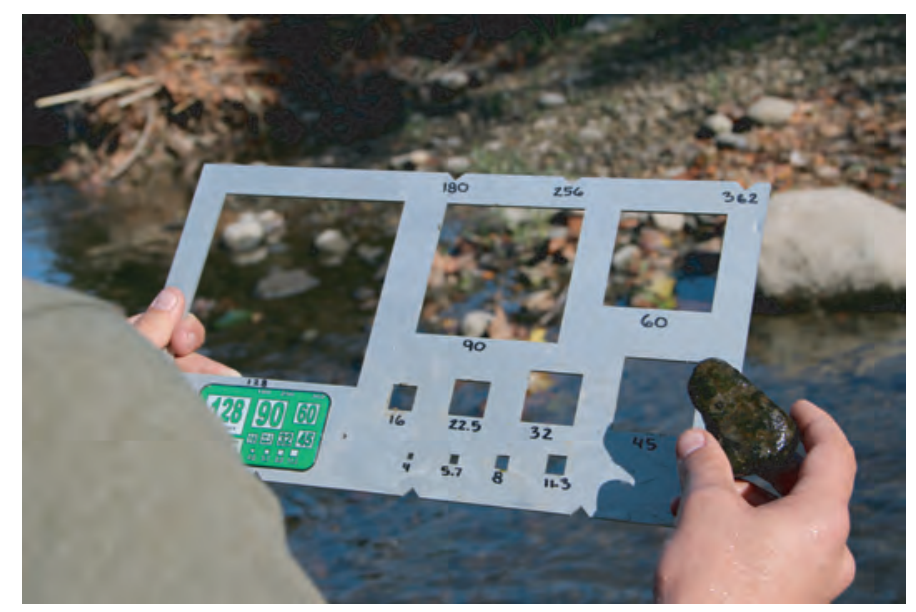

Figure 6. Gravelometer used to determine the dominant particle size of bed materials for sites with abundant gravel- and(or) cobble-sized particles.

criteria for a Rosgen class but did not resemble the Rosgenprovided descriptions or images. For these 24 sites, professional judgment was applied to determine if a single channel type could be identified as a reasonable fit for all site data and field observations. Even with this latitude, there were eight sites that were not classified because their measured characteristics or general appearance were judged to deviate too significantly from the Rosgen criteria, descriptions, and (or) images.

It should be noted that data-collection activities were completed only at sites where bankfull stage could be identified from physical evidence found in the field. With this restriction, the 82 study sites included, per the Rosgen classification system, 63 C-type channels, 4 E-type channels, 7 F-type channels, and 8 channels that did not produce an unambiguous and confident classification result (appendix 1). Although other channel types-A and $\mathrm{G}$ channels - were encountered in the field, they were not included for data collection because they typically do not yield an identifiable bankfull stage.

\section{Determinations of Drainage Area}

The USGS Web-based StreamStats tool for Indiana (http://streamstats.usgs.gov/indiana.html) was used to calculate the drainage area of each study site. When applying this tool, the user works with an interactive online map to identify their location of interest on a stream reach. The StreamStats tool then delineates the boundary of the watershed that drains to that location and allows the user to select, from a predefined list, the watershed characteristics to be calculated. For this investigation, drainage area was the key data element provided by StreamStats. 


\section{Regional Bankfull-Channel Dimensions}

Data analysis completed in this investigation closely followed the analysis path described by Sherwood and Huitger (2005). To begin this process, data from all 82 sites were combined and simple-regression analysis was performed to establish initial statewide relations between drainage area and bankfull-channel width, mean depth, and cross-sectional area. For each study site, these preliminary equations were used to calculate predicted channel-dimension values and residualspredicted values minus measured values. The residuals where then viewed in terms of their location within the state to determine if some areas showed a consistent pattern of overprediction or underprediction.

In this analysis, it was seen that the initial statewide equation overpredicted bankfull-channel width for 23 of the 25 sites measured in the Northern Moraine and Lake region and underpredicted bankfull-channel width for 25 of the 26 sites measured in the Southern Hills and Lowlands region. With this recognition, the data were then grouped by physiographic region and simple regression again was applied to develop more refined estimating equations. In each case, it was observed that the coefficient-of-determination values $\left(\mathrm{r}^{2}\right)$ produced by the grouped data were greater and thus indicated a better fit than the preliminary statewide regression equations.

Following the same procedure described above, the residuals calculated from the regional equations were viewed by location within their physiographic region. However, in this case there was no geographic pattern of overprediction or underprediction seen within the plotted residuals. From this analysis, it is concluded that the data best support regression equations and regional curves grouped by physiographic region.

It should be noted that an underlying assumption of linear-regression applications is that the residuals produced by the developed model(s) are normally distributed. To test for normality of residuals, the Kolmogorov-Smirnov Goodnessof-Fit (GOF) statistical test was applied to the residuals and regional bankfull-channel-dimension equations developed in this investigation. The p-value statistics generated from this test indicate that the residuals resulting from the predictive channel-dimension equations are in some cases not normally distributed. Therefore, the user should understand that, in addition to drainage area, there may well be other explanatory variables that influence channel dimensions but are not included in the simple regression equations discussed herein.

\section{Northern Moraine and Lake Region}

In many locations, the geologic materials underlying the Northern Moraine and Lake region are characterized as sandrich deposits associated with outwash, alluvial-fan aprons, and dunes (Gray, 2000). Excluding the alluvium associated with the largest river valleys in central and southern Indiana, this region generally has the most widespread and thickest sand deposits. The surface topography includes areas of low relief and areas of gently rolling moderate relief. Most of the large wetland areas that remain in Indiana are found within this region and, prior to draining for agricultural development, much of this region supported vast wetland complexes.

The Northern Moraine and Lake region held all of the E-type channels encountered during this investigation (appendix 1) and a reach of Little Elkhart Creek photographed in Wolcottville, Ind. (fig. $7 N$ ) was seen as representative of many of the channels in this region. Here, the channel of Little Elkhart Creek is sinuous but stable, with banks that are cohesive and well stabilized by a dense growth of grasses and herbaceous wetland plants. (In more rural locations within this physiographic region, the channelside vegetation also was seen to include significant amounts of woody vegetation adapted for growth in wetland settings.) The width/depth ratio is 10.9 , which generally describes a relatively narrow and deep channel. Even during a prolonged period of drought during the 2012 summer, water flow in this channel was seen to be well sustained by groundwater contributions. When considering all 82 data-collection sites, it appears that groundwater contributions may be one of the key parameters that distinguishes northern Indiana stream channels from the channels visited elsewhere.

In this region, bankfull-channel-dimension data were collected at a total of 25 sites (table 2). From these data, simple regression equations (table 5 ; equations 1,2 , and 3 ) and regional curves for bankfull-channel width, mean bankfull-channel depth, and bankfull-channel cross-sectional area (fig. 8) were developed. (Table 5 is found just ahead of the "Discussion" section.) 

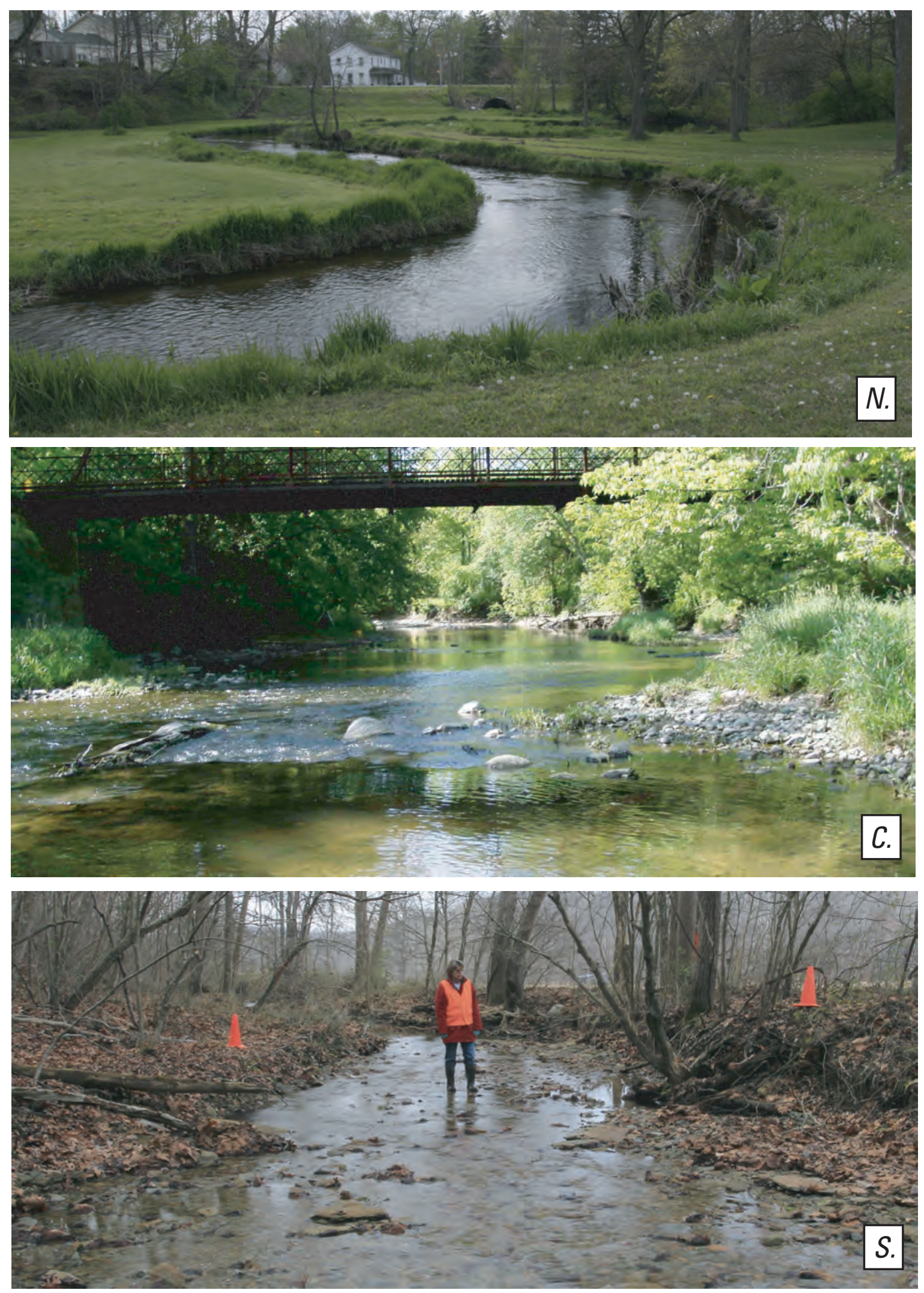

Figure 7. Three selected channel reaches generally seen to be representative of Indiana's contrasting physiographic regions: a reach of Little Elkhart Creek in Wolcottville $(N)$ in the Northern Moraine and Lake region, a reach of White Lick Creek at Avon $(C)$ in the Central Till Plain region, and an unnamed tributary to Bear Creek in Yellowwood State Forest $(S)$ in the Southern Hills and Lowlands region. 
Table 2. Drainage areas and bankfull-channel dimensions of study sites in the Northern Moraine and Lake region of Indiana.

\begin{tabular}{lcccc}
\hline $\begin{array}{c}\text { Site } \\
\text { identifier }\end{array}$ & $\begin{array}{c}\text { Drain- } \\
\text { age area } \\
\text { (miles }\end{array}$ & $\begin{array}{c}\text { ') } \\
\text { Bankfull- } \\
\text { channel } \\
\text { width (feet) }\end{array}$ & $\begin{array}{c}\text { Mean bank- } \\
\text { full-channel } \\
\text { depth (feet) }\end{array}$ & $\begin{array}{c}\text { Bankfull } \\
\text { cross- } \\
\text { sectional } \\
\text { area (feet }{ }^{2} \text { ) }\end{array}$ \\
\hline $\mathrm{RC}-100$ & 6.24 & 21.5 & 1.8 & 39.8 \\
\hline $\mathrm{RC}-101$ & 19.1 & 38.5 & 3.6 & 136.7 \\
\hline $\mathrm{RC}-102$ & 0.14 & 8.4 & 0.8 & 6.7 \\
\hline $\mathrm{RC}-103$ & 6.87 & 31.0 & 2.2 & 67.4 \\
\hline $\mathrm{RC}-104$ & 63.7 & 44.3 & 1.9 & 86.1 \\
\hline $\mathrm{RC}-105$ & 8.69 & 25.5 & 1.6 & 40.5 \\
\hline $\mathrm{RC}-106$ & 18.4 & 37.5 & 2.8 & 103.2 \\
\hline $\mathrm{RC}-107$ & 941 & 134.0 & 4.3 & 572.6 \\
\hline $\mathrm{RC}-108$ & 6.16 & 20.0 & 1.5 & 30.4 \\
\hline $\mathrm{RC}-109$ & 1.82 & 15.1 & 1.6 & 23.3 \\
\hline $\mathrm{RC}-110$ & 45.1 & 34.9 & 3.3 & 114.2 \\
\hline $\mathrm{RC}-111$ & 58.2 & 73.1 & 2.1 & 156.5 \\
\hline $\mathrm{RC}-112$ & 87.4 & 39.7 & 2.2 & 86.9 \\
\hline $\mathrm{RC}-113$ & 124 & 58.5 & 2.7 & 157.8 \\
\hline $\mathrm{RC}-114$ & 636 & 152.0 & 5.9 & 897.2 \\
\hline $\mathrm{RC}-115$ & 281 & 88.1 & 3.0 & 267.4 \\
\hline $\mathrm{RC}-116$ & 116 & 67.7 & 1.9 & 127.8 \\
\hline $\mathrm{RC}-117$ & 239 & 90.3 & 3.7 & 331.8 \\
\hline $\mathrm{RC}-118$ & 213 & 68.5 & 3.6 & 245.9 \\
\hline $\mathrm{RC}-119$ & 131 & 78.0 & 2.8 & 215.1 \\
\hline $\mathrm{RC}-120$ & 119 & 47.0 & 3.2 & 151.2 \\
\hline $\mathrm{RC}-121$ & 1.44 & 13.8 & 1.7 & 23.7 \\
\hline $\mathrm{RC}-122$ & .26 & 10.7 & .8 & 9.1 \\
\hline $\mathrm{RC}-123$ & 29.9 & 27.5 & 2.0 & 55.5 \\
\hline & 117 & 47.0 & 2.6 & 122.5 \\
\hline
\end{tabular}




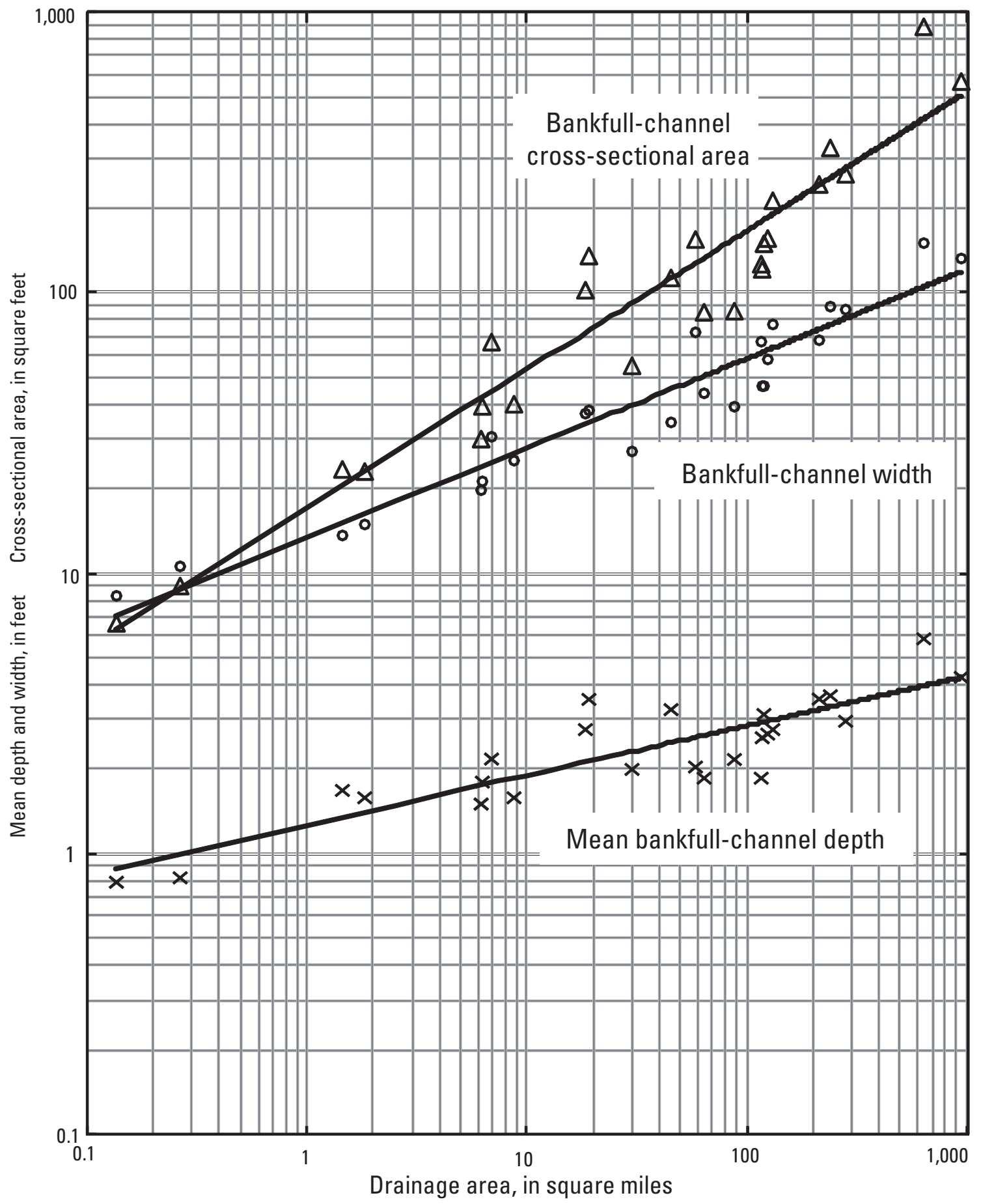

Figure 8. Regional channel-dimension curves for estimating bankfull-channel width, mean depth, and crosssectional area of non-urban wadeable streams in the Northern Moraine and Lake physiographic region of Indiana. 


\section{Central Till Plain Region}

The Central Till Plain region is described as an area underlain by thick sequences of cohesive, silt- and clay-rich till deposits (Gray, 2000). Except where it is dissected by the major streams of the region, overall upland relief is very low. Because many of the channels in this region are flowing on or attempting to cut into valley sides of erosion-resistant till, in many locations the boundary conditions of the channels are best characterized as semialluvial.

The 31 data-collection sites in this region included 21 C-type channels and $4 \mathrm{~F}$-type channels (appendix 1). The C-type reach of White Lick Creek at Avon, Ind. (fig. 7C) was seen as generally representative of the reaches where channel-dimension data were collected in the Central Till Plain physiographic region. At this location, the channel-boundary conditions can be described as fairly erosion resistant. The point bar that defines the left bank (looking downstream) of the channel contains a cohesive mixture of coarse and fine grained alluvium and it is well stabilized by trees and grasses. Along its right bank, the channel is attempting to cut into the native till that underlies this area. In some locations, till also is exposed in the bed of the channel. Here the channel has limited sinuosity, a fairly gentle slope, and a regularly repeating pattern of riffles and pools. The channel had a measured width/depth ratio of 14.8 , which falls well within the range of values expected for $\mathrm{C}$-type channels.

In the Central Till Plain physiographic region, bankfullchannel-dimension data were collected at a total of 31 sites (table 3). From these data, simple regression equations (table 5 ; equations 4,5 , and 6 ) and regional curves for bankfullchannel width, mean bankfull-channel depth, and bankfullchannel cross-sectional area (fig. 9) were developed.
Table 3. Drainage areas and bankfull-channel dimensions of study sites in the Central Till Plain region of Indiana.

\begin{tabular}{|c|c|c|c|c|}
\hline $\begin{array}{c}\text { Site } \\
\text { identifier }\end{array}$ & $\begin{array}{l}\text { Drain- } \\
\text { age area } \\
\left.\text { (miles }{ }^{2}\right)\end{array}$ & $\begin{array}{c}\text { Bankfull- } \\
\text { channel } \\
\text { width (feet) }\end{array}$ & $\begin{array}{c}\text { Mean } \\
\text { bankfull- } \\
\text { channel } \\
\text { depth (feet) }\end{array}$ & $\begin{array}{l}\text { Bankfull } \\
\text { cross- } \\
\text { sectional } \\
\text { area }\left(\text { feet }^{2}\right)\end{array}$ \\
\hline $\mathrm{RC}-200$ & 0.62 & 24.0 & 1.8 & 42.4 \\
\hline RC-201 & .82 & 19.0 & 1.2 & 22.4 \\
\hline $\mathrm{RC}-202$ & 192 & 126.0 & 2.4 & 308.4 \\
\hline RC-203 & 29.4 & 47.5 & 3.3 & 157.1 \\
\hline $\mathrm{RC}-204$ & 20.4 & 54.5 & 2.6 & 143.0 \\
\hline $\mathrm{RC}-205$ & 98.8 & 69.7 & 3.0 & 208.1 \\
\hline $\mathrm{RC}-206$ & 131 & 91.0 & 5.4 & 498.4 \\
\hline $\mathrm{RC}-207$ & 32.2 & 52.7 & 4.3 & 224.3 \\
\hline $\mathrm{RC}-208$ & 660 & 174.0 & 6.8 & 1190.3 \\
\hline RC-209 & 79.4 & 102.1 & 4.1 & 414.4 \\
\hline $\mathrm{RC}-210$ & 9.69 & 34.5 & 2.9 & 99.0 \\
\hline $\mathrm{RC}-211$ & 2.06 & 31.2 & 1.8 & 54.7 \\
\hline $\mathrm{RC}-212$ & 240 & 127.0 & 6.5 & 820.5 \\
\hline $\mathrm{RC}-213$ & 51.3 & 74.0 & 5.0 & 371.7 \\
\hline $\mathrm{RC}-214$ & 14.7 & 46.4 & 1.4 & 63.2 \\
\hline $\mathrm{RC}-215$ & .32 & 15.8 & 1.6 & 22.8 \\
\hline $\mathrm{RC}-216$ & 2.67 & 22.7 & 2.3 & 52.3 \\
\hline $\mathrm{RC}-217$ & .58 & 12.1 & 1.5 & 18.7 \\
\hline $\mathrm{RC}-218$ & 6.89 & 42.0 & 1.3 & 56.1 \\
\hline $\mathrm{RC}-219$ & 682 & 153.3 & 2.1 & 315.5 \\
\hline $\mathrm{RC}-220$ & 445 & 141.5 & 4.3 & 612.6 \\
\hline $\mathrm{RC}-221$ & 506 & 93.6 & 2.0 & 184.3 \\
\hline $\mathrm{RC}-222$ & 28.7 & 48.4 & 4.6 & 223.3 \\
\hline $\mathrm{RC}-223$ & 75.9 & 79.5 & 5.4 & 427.1 \\
\hline $\mathrm{RC}-224$ & 812 & 166.5 & 3.3 & 548.6 \\
\hline $\mathrm{RC}-225$ & .15 & 7.2 & 0.8 & 6.0 \\
\hline $\mathrm{RC}-226$ & 1.09 & 14.1 & 1.7 & 23.3 \\
\hline $\mathrm{RC}-227$ & 3.12 & 19.0 & 1.6 & 31.3 \\
\hline $\mathrm{RC}-228$ & 16.4 & 28.8 & 1.8 & 53.0 \\
\hline $\mathrm{RC}-229$ & 1.76 & 19.4 & 1.4 & 26.5 \\
\hline $\mathrm{RC}-230$ & .04 & 7.8 & 1.0 & 7.8 \\
\hline
\end{tabular}




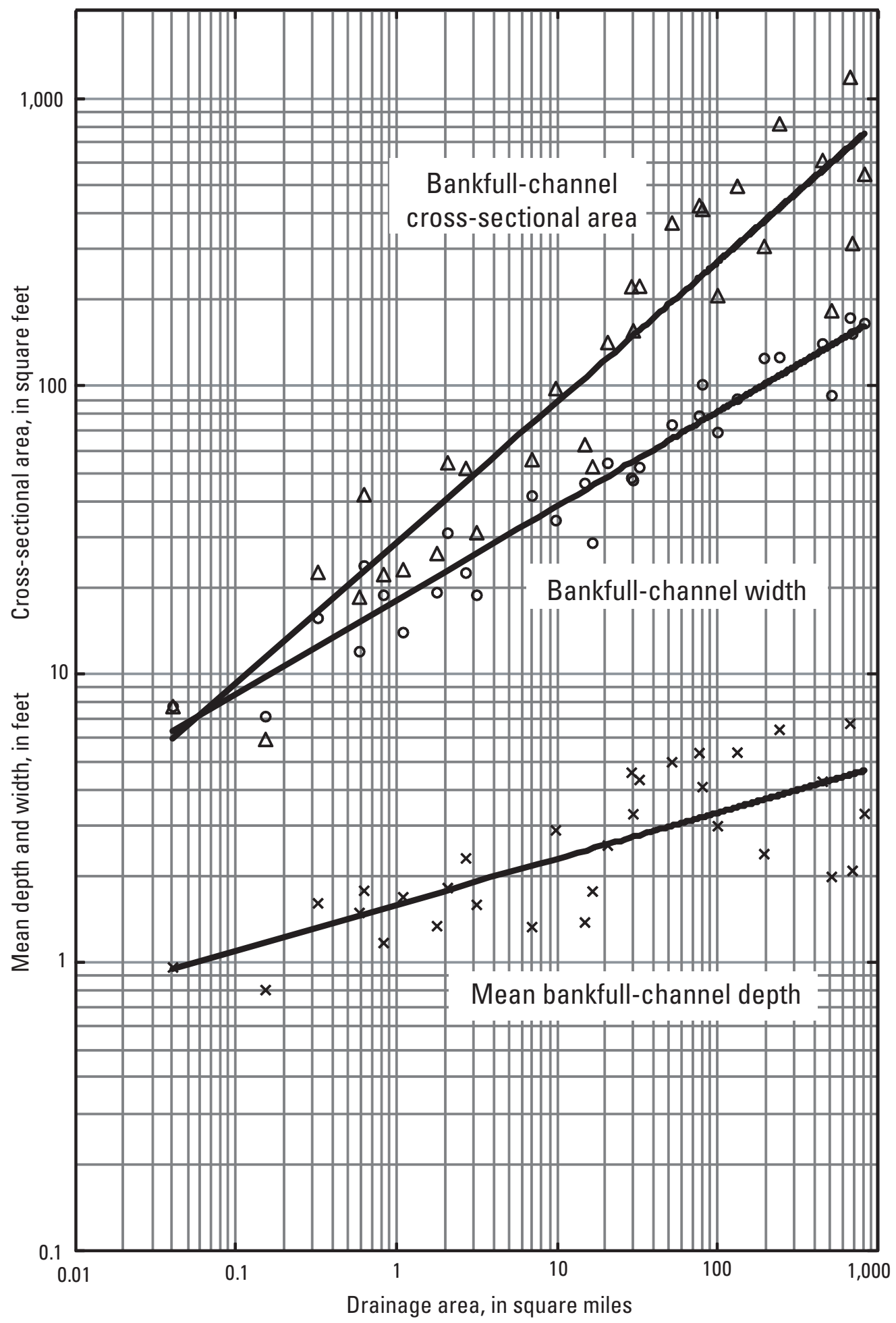

Figure 9. Regional channel-dimension curves for estimating bankfull-channel width, mean depth, and cross-sectional area of non-urban wadeable streams in the Central Till Plain physiographic region of Indiana. 


\section{Southern Hills and Lowlands Region}

Of the three physiographic regions discussed in this report, the Southern Hills and Lowlands region exhibits the greatest diversity of geologic and topographic character. In many locations, this physiographic region is beyond the southernmost glacial boundary in Indiana and underlying bedrock units are at or very near the land surface. The bedrock units that underlie this region gently dip to the west; into the Illinois Basin. The bedrock units most resistant to erosion form upland areas that roughly trend from north to south (fig. 1). Those bedrock units which are less resistant to erosion underlie the lowlands that run between uplands. This area of the state generally has the greatest local relief and highest drainage density; thereby producing Indiana's most rugged topography.

Table 4. Drainage areas and bankfull-channel dimensions of study sites in the Southern Hills and Lowlands region of Indiana.

\begin{tabular}{lcccc}
\hline $\begin{array}{c}\text { Site } \\
\text { identifier }\end{array}$ & $\begin{array}{c}\text { Drain- } \\
\text { age area } \\
\text { (miles }^{2} \text { ) }\end{array}$ & $\begin{array}{c}\text { Bankfull- } \\
\text { channel } \\
\text { width (feet) }\end{array}$ & $\begin{array}{c}\text { Mean } \\
\text { bankfull- } \\
\text { channel } \\
\text { depth (feet) }\end{array}$ & $\begin{array}{c}\text { Bankfull } \\
\text { cross- } \\
\text { sectional } \\
\text { area (feet }\end{array}$ \\
\hline RC-300 & 0.20 & 16.6 & 0.9 & 14.9 \\
\hline $\mathrm{RC}-301$ & 1.20 & 27.0 & 2.4 & 64.0 \\
\hline $\mathrm{RC}-302$ & 1.74 & 35.0 & 1.2 & 43.7 \\
\hline $\mathrm{RC}-303$ & 147 & 113.0 & 4.3 & 489.6 \\
\hline $\mathrm{RC}-304$ & .08 & 12.7 & .9 & 11.6 \\
\hline $\mathrm{RC}-305$ & .46 & 22.8 & 1.7 & 39.6 \\
\hline $\mathrm{RC}-306$ & 1.04 & 23.7 & 1.6 & 37.4 \\
\hline $\mathrm{RC}-307$ & .06 & 12.0 & .6 & 7.7 \\
\hline $\mathrm{RC}-308$ & 2.51 & 42.0 & 2.6 & 110.5 \\
\hline $\mathrm{RC}-309$ & .83 & 25.5 & 1.6 & 39.5 \\
\hline $\mathrm{RC}-310$ & 1.27 & 31.7 & 1.9 & 59.3 \\
\hline $\mathrm{RC}-311$ & .24 & 18.9 & 1.6 & 31.0 \\
\hline $\mathrm{RC}-312$ & 186 & 149.0 & 2.8 & 414.6 \\
\hline $\mathrm{RC}-313$ & 59.2 & 78.0 & 2.5 & 194.8 \\
\hline $\mathrm{RC}-314$ & 1.01 & 26.0 & 2.5 & 64.2 \\
\hline $\mathrm{RC}-315$ & 4.69 & 58.3 & 4.6 & 269.9 \\
\hline $\mathrm{RC}-316$ & 29.5 & 72.0 & 4.6 & 332.7 \\
\hline $\mathrm{RC}-317$ & 9.97 & 53.3 & 2.4 & 129.4 \\
\hline $\mathrm{RC}-318$ & 4.70 & 37.0 & 2.9 & 108.1 \\
\hline $\mathrm{RC}-319$ & 10.8 & 38.0 & 3.7 & 140.9 \\
\hline $\mathrm{RC}-320$ & .19 & 19.4 & 1.8 & 36.0 \\
\hline $\mathrm{RC}-321$ & .53 & 17.8 & 1.4 & 24.0 \\
\hline $\mathrm{RC}-322$ & 1.13 & 34.3 & 3.5 & 118.7 \\
\hline $\mathrm{RC}-323$ & .50 & 26.0 & 1.9 & 48.5 \\
\hline $\mathrm{R}-324$ & 1.09 & 25.6 & 2.2 & 57.7 \\
\hline & 7.53 & 41.7 & 3.3 & 136.9 \\
\hline
\end{tabular}

In this region, 22 of the 26 channel reaches selected for data acquisition were C-type channels (appendix 1). From all the sites visited here, an unnamed tributary to Bear Creek in Yellowwood State Forest (fig. 7S) was selected as representative of the channels in this region where data were collected. With nearby uplands cored by bedrock, this channel is in an area of high local relief and it has a relatively steep slope when compared to channel reaches measured in the northern and central portions of Indiana. Because the uplands tend to be steep and have relatively low infiltration capacities, rainstorms that produce high precipitation rates often lead to flashy runoff conditions in the channels and valley bottoms. The small channels in this region tend to have limited sinuosity; however, it is believed that in many cases this has resulted from the channels being straightened and forced to the valley side to accommodate agricultural pursuits in the valley bottoms (Parola and others, 2007).

In the figure 7 example, the channel bed and banks are clastic alluvium that may be easily eroded when channelfilling streamflows occur. This channel has a measured width/ depth ratio of 17.0, which generally indicates a relatively wide and shallow channel with a geometry adjusted to transport sediment as bedload (Ritter and others, 2011).

In this physiographic region, bankfull-channel-dimension data were collected at a total of 26 sites (table 4). From these data, simple regression equations (table 5 ; equations 7,8 , and 9) and regional curves for bankfull-channel width, mean bankfull-channel depth, and bankfull-channel cross-sectional area (fig. 10) were developed.

Table 5. Regression equations for estimating bankfull-channel dimensions of non-urban wadeable streams in Indiana.

[WBF, bankfull width, in feet; DBF, mean bankfull depth, in feet; ABF, bankfull cross-sectional area, in square feet; DA, drainage area, in square miles]

\begin{tabular}{lll}
\hline $\begin{array}{c}\text { Equation } \\
\text { number }\end{array}$ & \multicolumn{1}{c}{ Equation } & $\begin{array}{c}\text { Coefficient of } \\
\text { determination } \\
\text { (r-squared) }\end{array}$ \\
\hline \multicolumn{3}{c}{ Northern Moraine and Lake region } \\
\hline 1 & $\mathrm{WBFn}=13.4 \mathrm{DA}^{0.318}$ & 0.92 \\
2 & $\mathrm{DBFn}=1.3 \mathrm{DA}^{0.176}$ & 0.75 \\
3 & $\mathrm{ABFn}=17.0 \mathrm{DA}^{0.495}$ & 0.92 \\
& $\quad$ Central Till Plain region $^{0.327}$ & 0.94 \\
4 & $\mathrm{WBFc}=18.2 \mathrm{DA}^{0.327}$ & 0.56 \\
6 & $\mathrm{DBFc}=1.6 \mathrm{DA}^{0.159}$ & 0.88 \\
& $\mathrm{ABFc}=28.8 \mathrm{DA}^{0.487}$ & 0.94 \\
7 & $\mathrm{Southern} \mathrm{Hills}$ and Lowlands region \\
9 & $\mathrm{WBFs}=27.2 \mathrm{DA}^{0.286}$ & 0.58 \\
\hline & $\mathrm{DBFs}=1.9 \mathrm{DA}^{0.183}$ & 0.87 \\
\hline
\end{tabular}




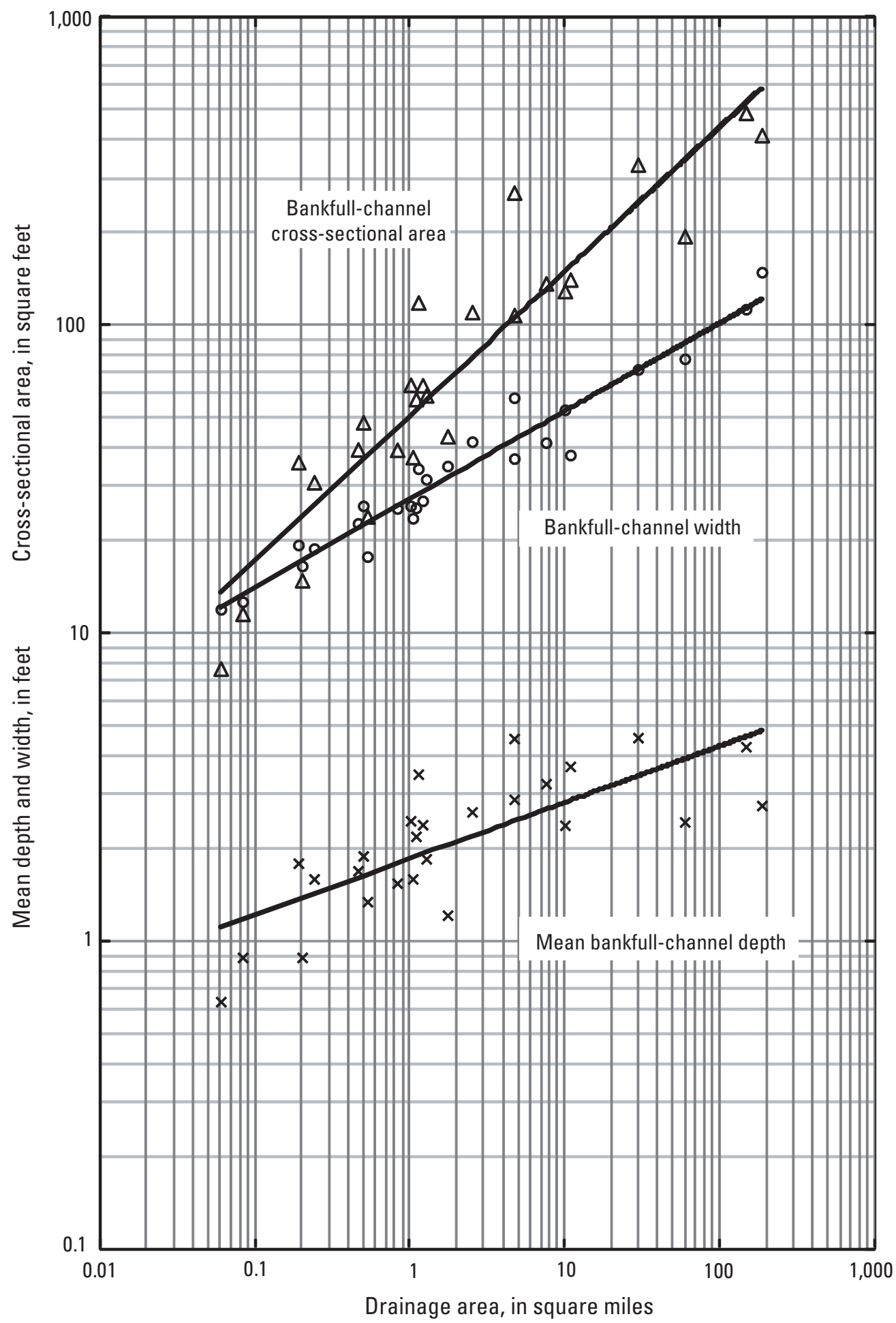

Figure 10. Regional channel-dimension curves for estimating bankfull-channel width, mean depth, and cross-sectional area of non-urban wadeable streams in the Southern Hills and Lowlands physiographic region of Indiana. 


\section{Discussion}

The channel-geometry and bankfull-channel-dimension data collected in this investigation reveal that the character and dimensions of stream channels in Indiana vary between physiographic regions. For any given drainage area, northern Indiana channels have the smallest predicted bankfull-channel dimensions, southern Indiana channels have the largest predicted bankfull-channel dimensions, and central Indiana channels are intermediate in their predicted dimensions (figs. 11, 12 , and 13). When considering the suite of variables that influence bankfull-channel dimensions, it appears that contrasting runoff characteristics between the three physiographic regions may explain much of the inequality observed.

In the Northern Moraine and Lake region, sand-rich deposits and a low-relief to gently rolling landscape promote the infiltration of precipitation. A map presented by Clark (1980) indicates that average annual runoff for some portions of northern Indiana is less than 10 in. per year and less than 60 percent of the runoff realized in some portions of southern Indiana. With less annual runoff, the channels of northern Indiana tend to be smaller than the channels of central and southern Indiana. The northern region also includes E-type channels, and streamflows tend to be more sustained by groundwater contributions.

In the Southern Hills and Lowlands region, near-surface bedrock and a rugged landscape character tend to promote rapid runoff. From Clark (1980) we see that, for much of southern Indiana, runoff is in excess of 14 in. per year. With a higher volume of runoff and a more flashy character, the predicted dimensions of southern Indiana channels tend to be larger than the channels of central and northern Indiana.

As mentioned previously, early work to document the relations between drainage area and bankfull-channel dimensions resulted in a published set of regional curves for the eastern United States (most often attributed to Dunne and Leopold, 1978). While the eastern United States regional curves have been and can be applied to Indiana streams, it should be recognized that those curves were derived from a fairly limited set of data and from data collected over a very broad geographic region. In this light, the bankfull-channeldimension curves established in this investigation can, for Indiana applications, be viewed as an attempted refinement of the eastern United States regional curves.

Estimates of bankfull-channel dimensions calculated from the curves identified for Indiana and the eastern United States regional curves (Dunne and Leopold, 1978) for streams with drainage areas of $0.5,1,5,25,50,100$, and $200 \mathrm{mi}^{2}$ are presented in table 6. This table also includes comparisons between the three Indiana curves and the eastern United States regional curves. For the range of drainage areas presented in the table, five generalities are recognized:

1. For the smallest sites (for example drainage areas ranging from 0.5 to $1 \mathrm{mi}^{2}$ ), the channel-dimension curves identified for northern Indiana streams generally confirm the dimensions predicted by the eastern United States regional curves.

2. As drainage area increases, there is greater disparity between the northern Indiana and eastern United States regional curves, and the northern Indiana curves consistently predict channel dimensions that are smaller than the dimensions predicted by the eastern United States curves.

3. For the smallest sites (again, drainage areas ranging from 0.5 to $1 \mathrm{mi}^{2}$ ), the southern Indiana regional curves predict channel widths that are approximately twice the widths predicted by the eastern United States regional curves.

4. As drainage area increases, the disparity between the southern Indiana and eastern United States regional curves decreases, and for sites with drainage areas ranging from 50 to $200 \mathrm{mi}^{2}$ the southern Indiana curves generally agree with the channel-dimension estimates derived from the eastern United States curves.

5. Over the entire range of drainage areas $\left(0.5\right.$ to $\left.200 \mathrm{mi}^{2}\right)$, results derived from the central Indiana curves produce channel-dimension estimates that are generally closest to results derived from the eastern United States regional curves.

For any application of regional bankfull-channeldimension curves, it is important that the user recognize that most often there is significant natural variability contained within the datasets used to establish the regional relations. An example of this natural variability is seen in the plot of mean bankfull-channel depth included in figure 9. In this plot (and in regional curves in general), the best fit line represents the central tendency of the measured data; however, it is readily apparent that very few of the measured data fall on the best fit line and many of the data points are well off of the best fit line. Therefore, while a best-fit line can be identified and a regression equation describing that line can be presented, it will be prudent for the user to consider the many variables that may influence channel dimensions and the scale of variability that may be present in the channel dimensions of any natural waterway. 
Table 6. Comparison of bankfull-channel-dimension estimates from Indiana and from regional curves for the eastern United States. [Regional curves for the eastern United States from Dunne and Leopold (1978). mi², square miles; $\mathrm{ft}$, feet; $\mathrm{ft}^{2}$, square feet]

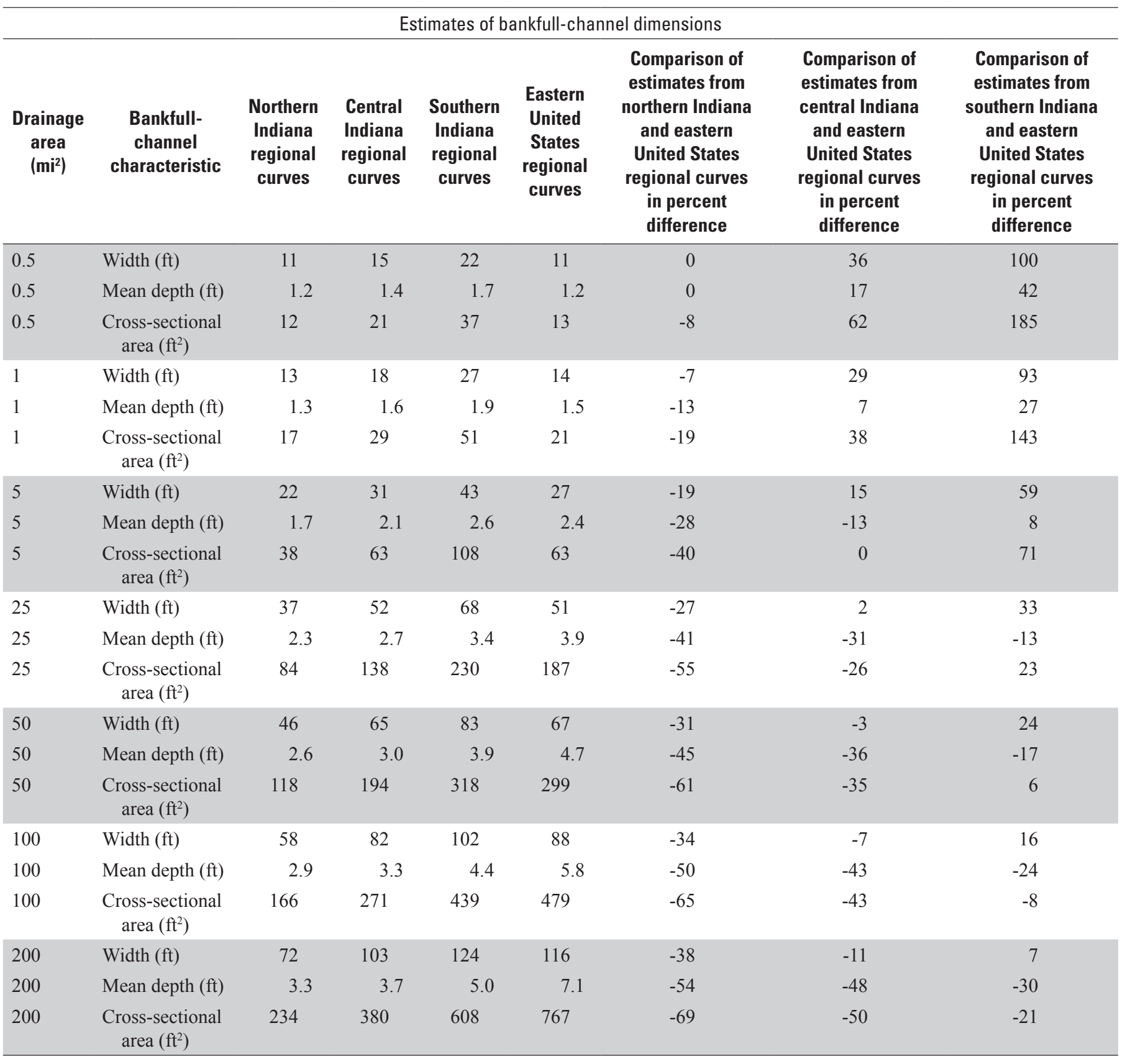




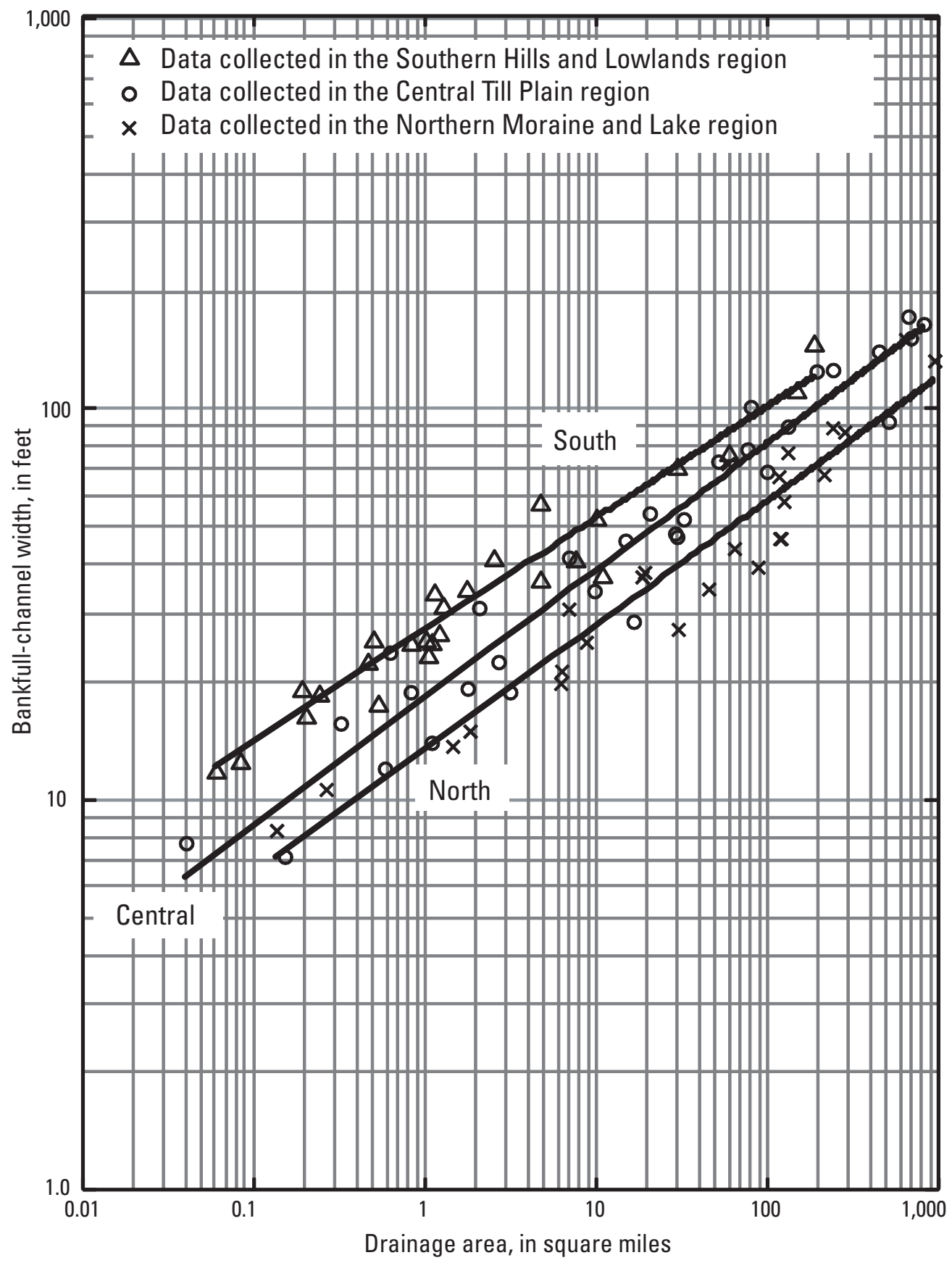

Figure 11. Comparison of the regional channel-dimension curves for estimating bankfull-channel width of non-urban wadeable streams in Indiana. 


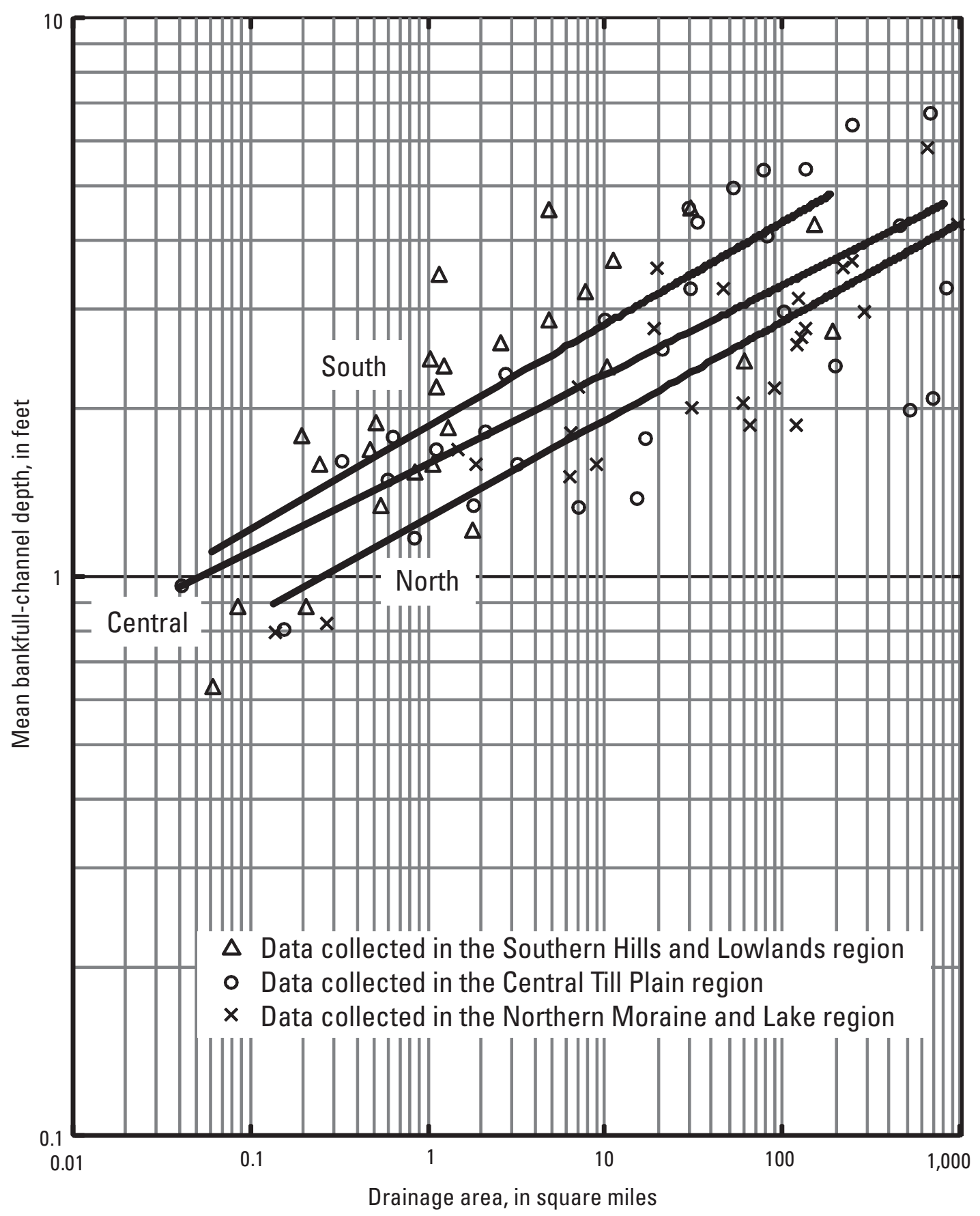

Figure 12. Comparison of the regional channel-dimension curves for estimating mean bankfull-channel depth of non-urban wadeable streams in Indiana. 


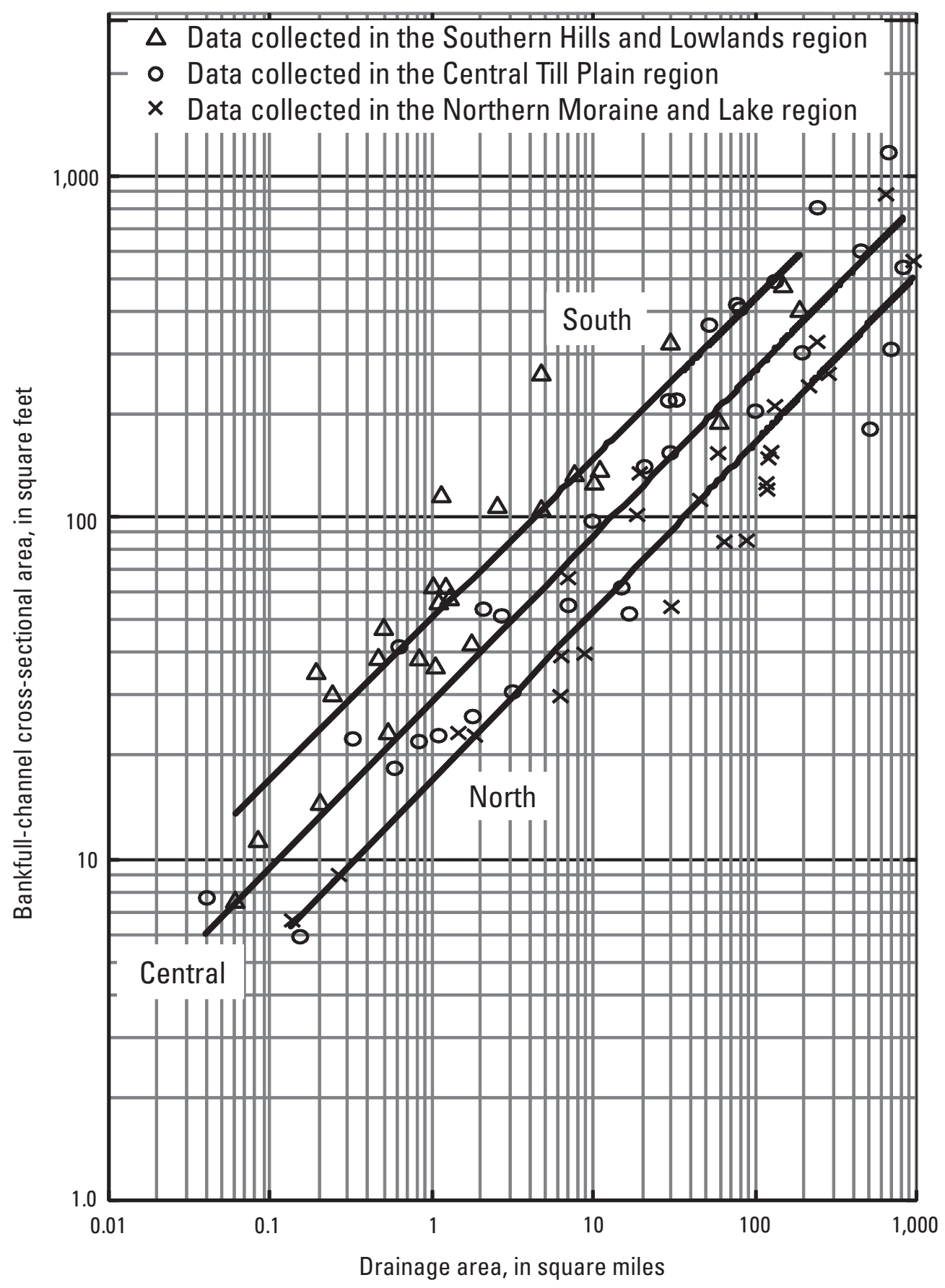

Figure 13. Comparison of the regional channel-dimension curves for estimating bankfull-channel cross-sectional area of non-urban wadeable streams in Indiana. 


\section{Limitations}

It should be noted that the regression equations and regional curves presented in this report were developed from a dataset that had geographic limitations. While substantial effort was applied to collect channel-dimension data from the broadest possible area, modifications to channels and channel networks impacted by drainage-improvement practices (for example tile drains and ditching) prevented data collection in some portions of Indiana. Therefore, when the results presented herein are applied, it will be prudent for the end user to consider where data were collected, where data are lacking, and incorporate knowledge gained from their own observations of local conditions.

Of particular note, there were no sites identified in a large portion of southwestern Indiana (fig. 3) where bankfullchannel-dimension data could be collected from stable and non-incised streams. This area is largely coincident with the Wabash Lowland physiographic division (Gray, 2000). Though this area is mapped as part of the Southern Hills and Lowlands region, its characteristics of low relief and thick sequences of till and alluvium may yield bankfull-channel dimensions that more closely follow the relations established for the Central Till Plain region to the immediate north. Therefore, because this area is not represented in the channeldimension dataset discussed herein, it is acknowledged that the channel-dimension relations identified for southern Indiana may not apply well in this area. All available resources should be considered when channel-dimension estimates are produced for channels in this area.

Likewise, the user should understand limitations within the channel-classification results (appendix 1). For several sites, the collected channel-geometry data produced ambiguous channel-classification results, and for a few sites the data did not fall within the defined range of any single channel type. Therefore, for many sites, professional judgment was applied to select the one channel type that best fit all site data and field observations. From experience gained in this investigation, it is anticipated that many channel reaches in Indiana will require careful consideration and professional judgment when Rosgen (1996) channel-classification is attempted.

\section{Summary and Conclusions}

Between 2006 and 2008, many areas of Indiana were impacted by damaging floods. While some of the damage resulted from inundation by flood waters, processes of erosion and channel migration also produced costly impacts. With this recognition, the Indiana Silver Jackets - a consortium of Federal and State agencies that focuses on reducing risks associated with natural hazards - identified regional channeldimension curves as one of the science-based tools that should be developed to support mitigation efforts associated with fluvial-erosion hazards.

Regional channel-dimension curves typically are presented as a combination of plots and regression equations that show the relation between drainage area and channel dimensions. In this investigation, the USGS has developed regional channel-dimension relations for non-urban wadeable streams in Indiana. These relations have been developed for the bankfull-channel dimensions of width, mean depth, and crosssectional area and describe how they relate to the predictive variable of drainage area. To ensure that channel-dimension data could be obtained from many sites with relatively small drainage areas, and because USGS streamgages are rarely established on sites with small drainage areas, the data-collection effort focused on ungaged sites across Indiana.

Because it was anticipated that channel dimensions might vary from south to north and between physiographic regions, the site-selection process tried to include a roughly equal number of sites from Indiana's Northern Moraine and Lake region, Central Till Plain region, and Southern Hills and Lowlands region. The site-selection process also tried to ensure that data would be collected over a broad range of drainage areas within each of these targeted physiographic regions. In total, 82 sites were identified for data collection; 25 in the Northern Moraine and Lake region, 31 in the Central Till Plain region, and 26 in the Southern Hills and Lowlands region.

Following well established methods, data were collected at each site to identify bankfull stage, determine the dimensions of bankfull width, mean depth, and cross-sectional area, and document channel-geometry characteristics that allowed for determinations of channel classification. From the channel-dimension data, preliminary statewide relations were developed that relate channel dimensions to drainage area. By evaluating where these statewide relations overpredicted and underpredicted the measured channel dimensions, it was identified that the data supported independent relations for each of the three physiographic regions.

In this investigation it was found that, for any given drainage area, northern Indiana channels have the smallest predicted dimensions, southern Indiana channels have the largest predicted dimensions, and central Indiana channels are intermediate in their predicted dimensions. When considering the suite of variables that influence channel dimensions, it appears that contrasting runoff characteristics between the three physiographic regions may explain much of the inequality observed in the measured channel dimensions.

The reader is cautioned that, while effort was applied to collect channel-dimension data from the broadest possible area, data collection was not possible in all portions of Indiana. Therefore, when the results presented herein are applied, it will be prudent for the user to incorporate knowledge gained from their own observations of local conditions. 


\section{References Cited}

Cinotto, P.J., 2003, Development of regional curves of bankfull-channel geometry and discharge for streams in the non-urban, Piedmont physiographic province, Pennsylvania and Maryland: U.S. Geological Survey Water-Resources Investigations Report 03-4014, 27 p.

Clark, G.D., ed., 1980, The Indiana water resource availability, uses, and needs: Indianapolis, Indiana Department of Natural Resources, $508 \mathrm{p}$.

Davis, W.M., 1899, The geographical cycle: The Geographical Journal, v. 14, no. 5, p. 481-504.

Dunne, T., and Leopold, L.B., 1978, Water in environmental planning: New York, W.H. Freeman and Company, 818 p.

Emmett, W.W., 2004, A historical perspective on regional channel geometry curves: U.S. Department of Agriculture, Stream Notes, accessed January 23, 2006, at http://stream. fs.fed.us/news/streamnt/jan04/jan04_02.htm.

Emmett, W.W., and Leopold, L.B., 1963, A dimensionless rating curve: U.S. Geological Survey, Water Resources Division Bulletin, August, 1963, p. 22-24.

Gray, H.H., 2000, Physiographic divisions of Indiana: Indiana University, Indiana Geological Survey Special Report 61, $15 \mathrm{p}$.

Harman, W.A., Jennings, G.D., Patterson, J.M., Clinton, D.R., Slate, L.O., Jessup, A.G., Everhart, J.R., and Smith, R.E., 1999, Bankfull hydraulic geometry relationships for North Carolina streams: American Water Resources Association Wildland Hydrology Symposium, Bozeman, Montana [Proceedings], accessed November 30, 2012, at http://www.bae. ncsu.edu/programs/extension/wqg/srp/rural_pied_paper. html.

Harrelson, C.C., Rawlins, C.L., and Potyondy, J.P., 1994, Stream channel reference sites: An illustrated guide to field techniques: U.S. Department of Agriculture, Forest Service, Rocky Mountain Forest and Range Experiment Station General Technical Report RM-245, 61 p.

Johnson, P.A., and Heil, T.M., 1996, Uncertainty in estimating bankfull conditions: American Water Resources Association Water Resources Bulletin, v. 32, no. 6, p. 1283-1291.

Juracek, K.E. and Fitzpatrick, F.A., 2003, Limitations and implications of stream classification: Journal of the American Water Resources Association, v. 39, no. 3, p. 659-670.

Lawlor, S.M., 2004, Determination of channel-morphology characteristics, bankfull discharge, and various design-peak discharges in western Montana: U.S. Geological Survey Scientific Investigations Report 2004-5263, 19 p.
Leopold, L.B., and Wolman, M.G., 1957, River channel patterns: braided, meandering, and straight: U.S. Geological Survey Professional Paper 282-B, 51 p.

Leopold, L.B., Wolman, M.G., and Miller, J.P., 1964, Fluvial processes in geomorphology: San Francisco, W.H. Freeman and Company, $522 \mathrm{p}$.

McCandless, T.L., and Everett, R.A., 2002, Maryland stream survey: bankfull discharge and channel characteristics of streams in the Piedmont hydrologic region: U.S. Fish and Wildlife Service CBFO-S02-01, 40 p.

Melton, F.A., 1936, An empirical classification of flood-plain streams: The Geographical Review, v. 26, p. 593-609.

Miller, J.R. and Ritter, J.B., 1996, An examination of the Rosgen classification of natural rivers: Catena, v. 27, p. 295-299.

Mistak, J.L., and Stille, D.A., 2008, Regional hydraulic geometry curve for the Upper Menominee River: Michigan Department of Natural Resources, Fisheries Technical Report 20081, accessed November 30, 2012, at http://www. michigan.gov/documents/dnr/2008-1tr_363056_7.pdf.

Montgomery, D.R., and Buffington, 1993, Channel classification, prediction of channel response and assessment of channel condition: Seattle, University of Washington, Department of Geological Sciences and Quaternary Research Center Report TFW-SH10-93-002, 84 p.

Morlock, S.E., Menke, C.D., Arvin, D.V., and Kim, M.H., 2008, Flood of June 7-9, 2008, in central and southern Indiana: U.S. Geological Survey Open-File Report 2008-1322, $15 \mathrm{p}$.

Parola, A.C., Vesely, W.S., Croasdaile, M.A., Hansen, C., and Jones, M.S., 2007, Geomorphic characteristics of streams in the Bluegrass physiographic region of Kentucky: Louisville, University of Louisville Stream Institute, Project final report for Kentucky Division of Water NPS 00-10, 60 p.

Powell, R.O., Miller, S.J., Westergard, B.E., Mulvihill, C.I., Baldigo, B.P., Gallagher, A.S., and Starr, R.R., 2003, Guidelines for surveying bankfull channel geometry and developing regional hydraulic-geometry relations for streams of New York State: U.S. Geological Survey Open-File Report 03-92, $20 \mathrm{p}$.

Ritter, D.F., Kochel, R.C., and Miller, J.R., 2011, Process geomorphology: Long Grove, Illinois, Waveland Press, Inc., $652 \mathrm{p}$.

Roper, B.B., Buffington, J.M., Archer, E., Moyer, C., and Ward, M., 2008, The role of observer variation in determining Rosen stream type in northeastern Oregon mountain streams: Journal of the American Water Resources Association, v. 44, no. 2, p. 417-427. 
Rosgen, D.L., 1994, A classification of natural rivers: Catena, v. 22 , no. 3, p. 169-199.

Rosgen, D.L., 1996, Applied river morphology: Pagosa Springs, Colorado, Wildland Hydrology, (variously paginated)

Schumm, S.A., 1963, A tentative classification of alluvial river channels: U.S. Geological Survey Circular 477, 10 p.

Sherwood, J.M., and Huitger, C.A., 2005, Bankfull characteristics of Ohio streams and their relation to peak streamflows: U.S. Geological Survey Scientific Investigations Report 2005-5153, 38 p.

Simon, A., Doyle, M., Kondolf, M., Shields, F.D., Jr., Rhoads, B., Grant, G., Fitzpatrick, F., Juracek, K., McPhillips, M., and MacBroom, J., 2005, How well do the Rosgen classification and associated natural channel design methods integrate and quantify fluvial processes and channel response?, in World Water Congress 2005: Impacts of global climate change: 2005 World Water and Environmental Resources Congress, Anchorage, Alaska [Proceedings], p. 584.

U.S. Department of Agriculture, 2003, Identifying bankfull stage in forested streams in the eastern United States: Stream Systems Technology Center, Rocky Mountain Research Station, Forest Service videotape, approx. 46 minutes.
Vermont Agency of Natural Resources, 2009a, Identification of bankfull stage: Vermont stream geomorphic assessment, appendix K: accessed November 30, 2012, at http://www.vtwaterquality.org/rivers/docs/ assessmenthandbooks/rv_apxkidbankfullstage.pdf.

Vermont Agency of Natural Resources, 2009b, Bridge and culvert assessment protocol: Vermont stream geomorphic assessment, appendix G: accessed February 5, 2013, at http://www.vtwaterquality.org/rivers $/ \mathrm{htm} / \mathrm{rv}$ _geoassess.htm.

White, K.E., 2001, Regional curve development and selection of a reference reach in the non-urban, Lowland sections of the Piedmont physiographic province, Pennsylvania and Maryland: U.S. Geological Survey Water-Resources Investigations Report 01-4146, 20 p.

Williams, G.R., 1978, Bank-full discharge of rivers: Water Resources Research, v. 14, no. 6, p. 1141-1154.

Wolman, M.G., 1954, A method of sampling coarse river-bed material: Transactions of the American Geophysical Union, v. 35, p. 951-956.

Wolman, M.G., and Miller, John C., 1960, Magnitude and frequency of forces in geomorphic processes: Journal of Geology, v. 68, p. 54-74. 


\section{Glossary}

The terms in this glossary were compiled from numerous sources. Some definitions have been modified for use within this report.

Alluvium Sediment deposits resulting from the operations of modern streams and rivers.

Bankfull channel The active stream channel during periods of bankfull discharge.

Bankfull cross-sectional area The surface area, measured perpendicular to streamflow and in the vertical plane, through which water passes during periods of bankfull discharge.

Bankfull discharge The water discharge that completely fills the active channel just prior to overflow spilling onto the attendant floodplain.

Bankfull mean depth Determined from a single measurement cross section, the average depth of the active channel at bankfull discharge.

Bankfull stage The elevation (or level) on a channel bank that defines incipient flooding.

Bankfull width The width of the water surface in the active channel, measured at bankfull discharge and perpendicular to flow.

Bedload Material transported by a stream through the processes of rolling, sliding, and saltation. Also, sediment particles that, when moved by the action of streamflow, are in frequent contact with the streambed.

Bed material The geologic materials found in the boundary — bed and banks — of a stream channel.

Drainage area A measure of the horizontal projection of the land-surface area that contributes runoff to an identified point of interest.

Entrenchment ratio The water-surface width at two times the maximum bankfull depth divided by the bankfull width.

Field indicators of bankfull stage Physical evidence, which may be observed in the field, to help identify bankfull stage.
Flooding An overflowing of water onto normally dry land.

Floodplain The flat area of land adjacent to a channel which, within the current climatic regime, has been constructed by processes associated with the stream, and is subject to recurring inundation.

Fluvial Of, or pertaining to, rivers and streams. Also, the landforms, geologic deposits, and processes associated with the actions of flowing water.

Fluvial-erosion hazard The suite of risks to structures, property, and infrastructure elements that are brought about by the natural processes of stream-bank erosion and stream-channel meandering.

Fluvial plain The valley-floor (or valleyflat) land that has been produced by fluvial processes and may include the floodplain and adjacent terraces.

Geomorphology The branch of geology that studies the landforms of the earth's surface and the processes that shape them.

Phototropic Growing toward a light source.

Physiographic region An area of common geologic materials, topographic character, and geomorphic history.

Regional curves Plots established to show the relations between drainage area and the bankfull-channel dimensions of width, mean depth, and cross-sectional area.

Root collar Typically found at ground level, the transition zone the separates the roots from the trunk of a tree.

Rosgen channel classification A system of describing river channels based on channel geometry, stream plan-view patterns, and streambed material. 
Sinuosity The ratio of channel length divided by the straight-line valley length between two end points that define a channel reach. A measure used to describe the amount a channel meanders.

Slope A measure of the vertical fall of a channel over a defined channel length; synonymous with gradient.

Wadeable A stream reach where it is practical for field observations and measurements to be completed while wading.

Watershed The land-surface area that potentially contributes surface runoff to an identified location; synonymous with drainage basin.

Width/depth ratio A term used to describe the general shape of a crosschannel profile; calculated by dividing the bankfull-channel width by the mean bankfull-channel depth. 
Appendix 1. Channel-Classification Data and Determinations for the ChannelDimension Study Sites on Non-Urban Wadeable Streams in Indiana 


\section{Appendix 1. Channel-classification data and determinations for the channel-dimension study sites on non-urban wadeable} streams in Indiana.

[Rosgen level II classification based on Rosgen (1996). <.less than; - , channel reaches with no classification results, ambiguous classification results, or other characteristic that did not result in a confident classification.]

\begin{tabular}{|c|c|c|c|c|c|c|}
\hline $\begin{array}{c}\text { Site } \\
\text { identification }\end{array}$ & $\begin{array}{c}\text { Slope } \\
\text { (feet/foot) }\end{array}$ & $\begin{array}{l}\text { Sinuosity } \\
\text { (feet/foot) }\end{array}$ & $\begin{array}{l}\text { Width/depth ratio } \\
\text { (feet/foot) }\end{array}$ & $\begin{array}{c}\text { Entrenchment } \\
\text { ratio (feet/foot) }\end{array}$ & $\begin{array}{c}\text { Dominant } \\
\text { channel material }\end{array}$ & $\begin{array}{c}\text { Rosgen II } \\
\text { classification' }\end{array}$ \\
\hline $\mathrm{RC}-100$ & 0.002 & 1.86 & 11.6 & 8.4 & Sand & $\mathrm{E} 5 \mathrm{~b}$ \\
\hline $\mathrm{RC}-101$ & $<0.001$ & 1.39 & 10.8 & 5.1 & Sand & $\mathrm{E} 5 \mathrm{~b}$ \\
\hline $\mathrm{RC}-102$ & .009 & 2.05 & 10.5 & 2.2 & Sand & $\mathrm{C} 5$ \\
\hline $\mathrm{RC}-103$ & .001 & 1.07 & 14.3 & 10.7 & Sand & $\mathrm{C} 5$ \\
\hline $\mathrm{RC}-104$ & $<0.001$ & 1.53 & 22.8 & 2.5 & Sand & $\mathrm{C} 5 \mathrm{c}-$ \\
\hline $\mathrm{RC}-105$ & .001 & 1.05 & 16.1 & 11.8 & Sand & $\mathrm{C} 5$ \\
\hline RC-106 & .002 & 1.14 & 13.6 & 7.2 & Sand & $\mathrm{C} 5$ \\
\hline $\mathrm{RC}-107$ & $<0.001$ & 1.96 & 31.4 & 2.6 & Sand & C5c- \\
\hline RC-108 & .004 & 1.86 & 13.1 & 5.8 & Sand & $\mathrm{E} 5 \mathrm{~b}$ \\
\hline $\mathrm{RC}-109$ & .002 & 1.37 & 9.8 & 10.9 & Gravel & $\mathrm{E} 4 \mathrm{~b}$ \\
\hline $\mathrm{RC}-110$ & .001 & 1.52 & 10.7 & 6.9 & Gravel & $\mathrm{C} 4$ \\
\hline $\mathrm{RC}-111$ & .001 & 1.41 & 34.1 & 5.5 & Sand & $\mathrm{C} 5$ \\
\hline $\mathrm{RC}-112$ & .001 & 1.96 & 18.1 & 8.9 & Sand & $\mathrm{C} 5$ \\
\hline $\mathrm{RC}-113$ & .001 & 1.16 & 21.7 & 3.6 & Gravel & $\mathrm{C} 4$ \\
\hline $\mathrm{RC}-114$ & .001 & 1.50 & 25.8 & 6.3 & Sand & $\mathrm{C} 5$ \\
\hline $\mathrm{RC}-115$ & $<0.001$ & 1.40 & 29.0 & 2.8 & Sand & $\mathrm{C} 5 \mathrm{c}-$ \\
\hline $\mathrm{RC}-116$ & .001 & 1.22 & 35.9 & 8.4 & Sand & $\mathrm{C} 5$ \\
\hline $\mathrm{RC}-117$ & $<0.001$ & 1.38 & 24.6 & 5.8 & Sand & $\mathrm{C} 5 \mathrm{c}-$ \\
\hline $\mathrm{RC}-118$ & $<0.001$ & 1.19 & 19.1 & 11.7 & Sand & $\mathrm{C} 5 \mathrm{c}-$ \\
\hline $\mathrm{RC}-119$ & .001 & 1.44 & 28.3 & 7.4 & Sand & $\mathrm{C} 5$ \\
\hline $\mathrm{RC}-120$ & .001 & 1.29 & 14.6 & 7.2 & Gravel & $\mathrm{C} 4$ \\
\hline $\mathrm{RC}-121$ & .003 & 1.18 & 8.0 & 26.0 & Sand & - \\
\hline $\mathrm{RC}-122$ & .007 & 1.00 & 12.6 & 2.3 & Sand & $\mathrm{C} 5$ \\
\hline $\mathrm{RC}-123$ & $<0.001$ & 1.11 & 13.5 & 10.5 & Sand & $\mathrm{C} 5 \mathrm{c}-$ \\
\hline $\mathrm{RC}-124$ & .002 & 1.51 & 18.0 & 5.5 & Sand & $\mathrm{C} 5$ \\
\hline $\mathrm{RC}-200$ & .009 & 1.14 & 13.6 & 4.2 & Gravel & $\mathrm{C} 4$ \\
\hline $\mathrm{RC}-201$ & .010 & 1.18 & 16.1 & 1.9 & Gravel & - \\
\hline $\mathrm{RC}-202$ & .006 & 1.08 & 51.5 & 2.2 & Bedrock $^{2}$ & $\mathrm{C} 1$ \\
\hline $\mathrm{RC}-203$ & .002 & 1.49 & 14.4 & 9.7 & Gravel & $\mathrm{C} 4$ \\
\hline $\mathrm{RC}-204$ & .004 & 1.23 & 20.8 & 4.2 & Gravel & $\mathrm{C} 4$ \\
\hline $\mathrm{RC}-205$ & .001 & 1.04 & 23.3 & 4.0 & Gravel & $\mathrm{C} 4$ \\
\hline $\mathrm{RC}-206$ & .003 & 1.26 & 17.0 & 14.2 & Gravel & $\mathrm{C} 4$ \\
\hline RC-207 & $<0.001$ & 1.30 & 12.4 & 8.5 & Sand & C5c- \\
\hline $\mathrm{RC}-208$ & .003 & 1.50 & 25.4 & 2.2 & Bedrock & $\mathrm{C} 1$ \\
\hline RC-209 & .001 & 1.13 & 25.2 & 7.0 & Bedrock & $\mathrm{C} 1$ \\
\hline $\mathrm{RC}-210$ & .003 & 1.29 & 12.0 & 7.0 & Gravel & $\mathrm{C} 4$ \\
\hline $\mathrm{RC}-211$ & .012 & 1.46 & 17.8 & 16.0 & Cobble & $\mathrm{C} 3$ \\
\hline $\mathrm{RC}-212$ & .002 & 1.50 & 19.7 & 13.4 & Gravel & $\mathrm{C} 4$ \\
\hline $\mathrm{RC}-213$ & .004 & 1.19 & 14.7 & 9.7 & Gravel & $\mathrm{C} 4$ \\
\hline $\mathrm{RC}-214$ & .005 & 1.29 & 34.1 & 1.3 & Gravel & F4 \\
\hline $\mathrm{RC}-215$ & .008 & 1.84 & 8.8 & 13.1 & Silt/Clay & - \\
\hline $\mathrm{RC}-216$ & .004 & 1.49 & 9.9 & 6.3 & Gravel & - \\
\hline $\mathrm{RC}-217$ & .004 & 1.35 & 7.8 & 18.4 & Silt/Clay & - \\
\hline
\end{tabular}




\section{Appendix 1. Channel-classification data and determinations for the channel-dimension study sites on non-urban wadeable streams in Indiana._Continued}

[Rosgen level II classification based on Rosgen (1996). <.less than; - , channel reaches with no classification results, ambiguous classification results, or other characteristic that did not result in a confident classification.]

\begin{tabular}{|c|c|c|c|c|c|c|}
\hline $\begin{array}{c}\text { Site } \\
\text { identification }\end{array}$ & $\begin{array}{c}\text { Slope } \\
\text { (feet/foot) }\end{array}$ & $\begin{array}{l}\text { Sinuosity } \\
\text { (feet/foot) }\end{array}$ & $\begin{array}{c}\text { Width/depth ratio } \\
\text { (feet/foot) }\end{array}$ & $\begin{array}{l}\text { Entrenchment } \\
\text { ratio (feet/foot) }\end{array}$ & $\begin{array}{c}\text { Dominant } \\
\text { channel material }\end{array}$ & $\begin{array}{c}\text { Rosgen II } \\
\text { classification }^{1}\end{array}$ \\
\hline $\mathrm{RC}-218$ & .001 & 1.21 & 31.4 & 3.9 & Gravel & $\mathrm{C} 4$ \\
\hline $\mathrm{RC}-219$ & .002 & 1.37 & 74.7 & 1.4 & Bedrock & $\mathrm{F} 1$ \\
\hline $\mathrm{RC}-220$ & $<0.001$ & 2.40 & 32.7 & 4.2 & Gravel & $\mathrm{C} 4 \mathrm{c}-$ \\
\hline $\mathrm{RC}-221$ & $<0.001$ & 1.05 & 47.5 & 1.4 & Bedrock & $\mathrm{F} 1$ \\
\hline $\mathrm{RC}-222$ & $<0.001$ & 1.12 & 10.5 & 6.4 & Sand & C5c- \\
\hline $\mathrm{RC}-223$ & .001 & 1.40 & 14.8 & 11.1 & Sand & C5 \\
\hline $\mathrm{RC}-224$ & .001 & 1.35 & 50.5 & 1.4 & Gravel & $\mathrm{F} 4$ \\
\hline $\mathrm{RC}-225$ & .018 & 1.00 & 8.6 & 2.0 & Sand & - \\
\hline $\mathrm{RC}-226$ & $<0.001$ & 1.01 & 8.5 & 28.4 & Sand & - \\
\hline $\mathrm{RC}-227$ & .001 & 1.60 & 11.5 & 10.0 & Gravel & $\mathrm{C} 4$ \\
\hline $\mathrm{RC}-228$ & .007 & 1.05 & 15.7 & 11.5 & Sand & $\mathrm{C} 5$ \\
\hline $\mathrm{RC}-229$ & .020 & 1.37 & 14.2 & 11.6 & Gravel & $\mathrm{C} 4$ \\
\hline $\mathrm{RC}-230$ & .008 & 1.38 & 7.8 & 7.6 & Silt/Clay & C6 \\
\hline $\mathrm{RC}-300$ & .010 & 1.12 & 18.5 & 3.7 & Gravel & $\mathrm{C} 4$ \\
\hline $\mathrm{RC}-301$ & .005 & 1.16 & 11.4 & 13.0 & Gravel & $\mathrm{C} 4$ \\
\hline $\mathrm{RC}-302$ & .009 & 1.22 & 28.0 & 8.2 & Gravel & $\mathrm{C} 4$ \\
\hline $\mathrm{RC}-303$ & .002 & 1.63 & 26.1 & 2.2 & Gravel & $\mathrm{C} 4$ \\
\hline $\mathrm{RC}-304$ & .019 & 1.35 & 13.9 & 31.5 & Gravel & $\mathrm{C} 4$ \\
\hline $\mathrm{RC}-305$ & .005 & 1.26 & 13.1 & 18.4 & Gravel & $\mathrm{C} 4$ \\
\hline $\mathrm{RC}-306$ & .011 & 1.11 & 15.0 & 8.5 & Gravel & $\mathrm{C} 4$ \\
\hline $\mathrm{RC}-307$ & .007 & 1.31 & 18.7 & 4.0 & Gravel & $\mathrm{C} 4$ \\
\hline $\mathrm{RC}-308$ & .004 & 1.07 & 16.0 & 8.2 & Gravel & $\mathrm{C} 4$ \\
\hline $\mathrm{RC}-309$ & .009 & 1.10 & 16.5 & 13.0 & Gravel & $\mathrm{C} 4$ \\
\hline $\mathrm{RC}-310$ & .008 & 1.17 & 16.9 & 9.9 & Gravel & $\mathrm{C} 4$ \\
\hline $\mathrm{RC}-311$ & .013 & 1.10 & 11.5 & 5.92 & Gravel & $\mathrm{C} 4$ \\
\hline $\mathrm{RC}-312$ & .002 & 1.84 & 53.6 & 1.3 & Cobble & F3 \\
\hline $\mathrm{RC}-313$ & .001 & 1.18 & 31.2 & 1.2 & Bedrock & $\mathrm{F} 1$ \\
\hline $\mathrm{RC}-314$ & .013 & 1.12 & 10.5 & 16.4 & Gravel & $\mathrm{C} 4$ \\
\hline $\mathrm{RC}-315$ & .006 & 1.11 & 12.6 & 9.5 & Gravel & $\mathrm{C} 4$ \\
\hline $\mathrm{RC}-316$ & .001 & 1.76 & 15.6 & 1.4 & Sand & F5 \\
\hline $\mathrm{RC}-317$ & $<0.001$ & 1.15 & 22.0 & 3.9 & Bedrock & C1c- \\
\hline $\mathrm{RC}-318$ & .001 & 1.20 & 12.7 & 10.8 & Gravel & $\mathrm{C} 4$ \\
\hline $\mathrm{RC}-319$ & .002 & 1.28 & 10.3 & 6.3 & Bedrock & $\mathrm{C} 1$ \\
\hline $\mathrm{RC}-320$ & .020 & 1.08 & 10.5 & 5.4 & Cobble & $\mathrm{C} 3$ \\
\hline $\mathrm{RC}-321$ & .010 & 1.24 & 13.2 & 22.1 & Gravel & $\mathrm{C} 4$ \\
\hline $\mathrm{RC}-322$ & .009 & 1.13 & 9.9 & 2.0 & Bedrock & - \\
\hline $\mathrm{RC}-323$ & .012 & 1.25 & 13.9 & 7.0 & Gravel & $\mathrm{C} 4$ \\
\hline $\mathrm{RC}-324$ & .007 & 1.20 & 11.4 & 9.8 & Gravel & $\mathrm{C} 4$ \\
\hline $\mathrm{RC}-325$ & $<0.001$ & 1.33 & 12.7 & 19.2 & Bedrock & C1c- \\
\hline
\end{tabular}

${ }^{1}$ The definitive-criteria ranges used to determine reach classification were taken from Rosgen (1996) figure 5-3 and the variable ranges noted in the key of that figure were applied.

${ }^{2}$ At sites where bedrock is identified as the dominant channel material, more than 50 percent of the channel boundary was exposed bedrock; however, in all cases some portion of the channel boundary was also clastic alluvium. 




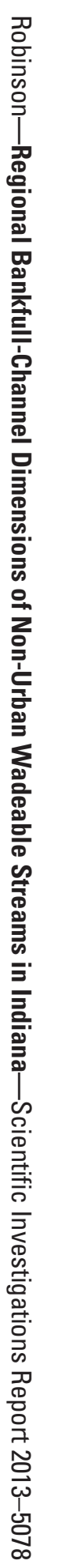

